\title{
Dust deposition: iron source or sink? A case study
}

\author{
Y. Ye ${ }^{1}$, T. Wagener ${ }^{2, *}$, C. Völker ${ }^{1}$, C. Guieu ${ }^{3}$, and D. A. Wolf-Gladrow ${ }^{1}$ \\ ${ }^{1}$ Alfred Wegener Institute for Polar and Marine Research, Bremerhaven, Germany \\ ${ }^{2}$ IFM-GEOMAR, Leibniz-Institut für Meereswissenschaften, Kiel, Germany \\ ${ }^{3}$ INSU-CNRS, UMR7093, Laboratoire d'Océanographie de Villefranche/Mer (LOV), Université Paris 06, \\ Observatoire Océanologique de Villefranche-sur-mer, France, Villefranche-sur-mer, France \\ *now at: LOPB, UMR6535, CNRS Université de la Méditerranee, Marseille, France
}

Received: 3 November 2010 - Published in Biogeosciences Discuss.: 21 December 2010

Revised: 13 May 2011 - Accepted: 23 July 2011 - Published: 4 August 2011

\begin{abstract}
A significant decrease of dissolved iron (DFe) concentration has been observed after dust addition into mesocosms during the DUst experiment in a low Nutrient low chlorophyll Ecosystem (DUNE), carried out in the summer of 2008. Due to low biological productivity at the experiment site, biological consumption of iron can not explain the magnitude of DFe decrease. To understand processes regulating the observed DFe variation, we simulated the experiment using a one-dimensional model of the Fe biogeochemical cycle, coupled with a simple ecosystem model. Different size classes of particles and particle aggregation are taken into account to describe the particle dynamics. DFe concentration is regulated in the model by dissolution from dust particles and adsorption onto particle surfaces, biological uptake, and photochemical mobilisation of particulate iron.

The model reproduces the observed DFe decrease after dust addition well. This is essentially explained by particle adsorption and particle aggregation that produces a high export within the first $24 \mathrm{~h}$. The estimated particle adsorption rates range between the measured adsorption rates of soluble iron and those of colloidal iron, indicating both processes controlling the DFe removal during the experiment. A dissolution timescale of 3 days is used in the model, instead of an instantaneous dissolution, underlining the importance of dissolution kinetics on the short-term impact of dust deposition on seawater DFe.
\end{abstract}

Sensitivity studies reveal that initial DFe concentration before dust addition was crucial for the net impact of dust addition on DFe during the DUNE experiment. Based on the balance between abiotic sinks and sources of DFe, a critical $\mathrm{DFe}$ concentration has been defined, above which dust depo-

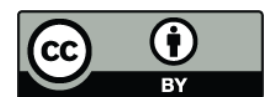

Correspondence to: $\mathrm{Y}$. Ye (ying.ye@awi.de) sition acts as a net sink of DFe, rather than a source. Taking into account the role of excess iron binding ligands and biotic processes, the critical DFe concentration might be applied to explain the short-term variability of DFe after natural dust deposition in various different ocean regions.

\section{Introduction}

Iron is an essential micronutrient for marine life. Due to its low solubility under oxic conditions, the bioavailability of iron in the ocean is often limited. The important role of iron in controlling marine primary production has been widely confirmed in bottle incubation and in situ iron fertilisation experiments over the last decades (Martin et al., 1990; Hutchins and Bruland, 1998; Mills et al., 2004; de Baar et al., 2005; Boyd et al., 2007). One of the major sources of iron in open ocean regions is the atmospheric input of dust (Duce and Tindale, 1991; Jickells et al., 2005). The impact of dust deposition on biological activities has been investigated in several modelling (e.g. Moore and Braucher, 2008; Aumont et al., 2008; Tagliabue et al., 2009) and laboratory studies (e.g. Mills et al., 2004; Herut et al., 2005; Reche et al., 2009). For instance, Mills et al. (2004) found in a shipboard experiment that dust addition stimulated a significant growth of chlorophyll. Some field studies in the HNLC (high-nutrientlow-chlorophyll) and oligotrophic waters also reported enhancement of biomass following natural dust deposition, in particular by nitrogen fixers; whereas others found no evidence of a response or low biological responses to dust supply (Boyd et al., 2010). The difference between these observations is attributed to limiting factors other than iron, e.g. phosphorus and light (Sedwick et al., 2005; Boyd et al.,

Published by Copernicus Publications on behalf of the European Geosciences Union. 
2004), but also to complex processes controlling the bioavailability of iron supplied by dust events.

The bioavailable fraction of iron input by atmospheric deposition strongly depends on dissolution and removal processes in seawater. Elevated concentrations of dissolved iron $(\mathrm{DFe})$ in surface waters following dust events have been widely observed (Vink and Measures, 2001; Bishop et al., 2002; Sarthou et al., 2003; Johnson et al., 2003; Rijkenberg et al., 2008), although the reported Fe solubility shows a large range from 0.01-80\% (Mahowald et al., 2009). Interactions with organic Fe binding ligands are supposed to alter the solubility of deposited iron (Baker and Croot, 2010).

Since the studies on loss processes of iron in seawater in the 1980's (e.g. Balistieri et al., 1981; Honjo et al., 1982), it is well known that iron has the metallic property to adsorb onto the surface of sinking particles and is removed out of the dissolved pool. The measured sorption time varies from hours to days (Nyffeler et al., 1984; Honeyman et al., 1988), indicating that several different processes regulate the adsorption kinetics. Importance has been attached to a pathway called "colloidal pumping" by Honeyman and Santschi (1989). "Colloidal pumping" describes the removal of particle-reactive trace metals such as thorium or iron via colloid formation and aggregation. The kinetics of these reactions has been further investigated in a few studies (Wells and Goldberg, 1993; Johnson et al., 1994; Wen et al., 1997; Rose and Waite, 2003b; Pham et al., 2006). Measurements on colloidal and particulate iron are however very limited in number and the chemical properties of particulate iron in the ocean are largely unknown (Bruland and Rue, 2001; Moffet, 2001). One of the most important issues in study on the marine Fe cycle is still how adsorptive scavenging and solubilisation of particulate iron influence the steady state concentration of DFe.

Dust deposition plays a double role in regulating iron concentration in seawater. Besides the dissolution of iron from dust particles, dust particles provide surfaces for adsorption. They are also involved in particle aggregation and act as ballast for sinking organic material (e.g. Armstrong et al., 2002; Ternon et al., 2010), changing the settling velocity of iron adsorbed on particle surfaces. The net effect of dust deposition on DFe in surface waters is therefore influenced by various factors: while the input flux of iron is mainly determined by the Fe solubility and content in dust particles, the loss flux depends on the size and composition of sinking particles, rates of particle aggregation as well as of the Fe adsorption and desorption at particle surfaces. Dust deposition does not only supply Fe but also other nutrients like P (Baker et al., 2003; Ridame and Guieu, 2002). Phytoplankton growth induced by this nutrient supply changes the strength of biological $\mathrm{Fe}$ cycling and thus DFe concentration in surface waters.

To better understand ecosystem responses to dust addition, a DUst experiment in a low Nutrient low chlorophyll Ecosystem (DUNE) was carried out in the preservation area of Scandola (Corsica) in the summer of 2008 (Guieu et al., 2010).
One focus of this project is to investigate the role of dust particles at Fe cycling in a high temporal and spatial resolution. Processed dust particles were added into mesocosms. Within the first hours after the dust addition, a rapid decrease of DFe concentration inside the mesocosms was observed and this lower concentration remained until the end of the experiment ( 8 days after the dust addition). This indicates a predominant effect of adsorptive scavenging compared to Fe dissolution from dust particles (Wagener et al., 2010).

In this study, we simulate the DUNE experiment using a one-dimensional model of the Fe cycle. Fe speciation and particle dynamics are described based on prior model studies by Weber et al. (2007) and Ye et al. (2009), and simplified for the DUNE experiment. We aim to explain mechanisms controlling the observed decrease of DFe following dust addition by:

1. discussing how the dissolution of iron from dust particles regulates the iron input;

2. estimating the adsorption rate constant needed for reproducing the observed DFe concentrations;

3. testing hypotheses on why the dust addition in the DUNE experiment was a net sink of DFe.

\section{DUNE experiment description}

In June 2008, six mesocosms were deployed in the preservation area of Scandola near Corsica $\left(42.37^{\circ} \mathrm{N}, 8.55^{\circ} \mathrm{E}\right)$. The mesocosms were cylindrical with a diameter of $2.3 \mathrm{~m}$ and a volume of $52 \mathrm{~m}^{3}$, enclosing an upper water layer of $15 \mathrm{~m}$. Details of the mesocosm construction have been described in Guieu et al. (2010). After deployment and closing of the mesocosms, the initial conditions of the experiment were measured. Dust particles were collected in a dust source area in southern Tunisia and processed by physico-chemical treatment in laboratory to mimic the ageing of dust particles by cloud cycling. These particles contain $4.12 \pm 0.39 \% \mathrm{Al}$ and $2.31 \pm 0.04 \%$ Fe by weight (Guieu et al., 2010). Three of the mesocosms (DUST-meso) each had $41.5 \mathrm{~g}$ of the processed dust particles added with a trace metal clean water spray to simulate a wet dust deposition of $10 \mathrm{~g} \mathrm{~m}^{-2}$. The addition lasted for $60 \mathrm{~min}$. No dust was added to the other three mesocosms used as control (CONTROL-meso). Sampling was performed daily for 3 depths $(0,5$ and $10 \mathrm{~m})$ during 8 days to determine particulate aluminium (PAl), dissolved (DFe) and particulate iron ( $\mathrm{PFe})$, and chlorophyll concentration (Chl). Every $48 \mathrm{~h}$, sediment traps at the bottom of the mesocosms were recovered and replaced to determine the fluxes of total mass, inorganic and organic carbon, nitrogen, total iron and aluminium.

The DUNE experiment site is representative of typical oligotrophic conditions of the open ocean (Guieu et al., 2010). Concentrations of dissolved inorganic phosphorus (DIP) are in the range of observations in the summer 
mixed layer in the open Mediterranean Sea (Pulido-Villena et al., 2010) where P-limitation of biological activity has been extensively reported (e.g. Thingstad et al., 1998). A macronutrient-depleted but Fe-replete site is optimal for investigating the physico-chemical processes controlling $\mathrm{Fe}$ speciation and removal, because the biological uptake and remineralisation of iron only play a minor role in the $\mathrm{Fe}$ cycling. Thanks to the original design of the clean mesocosms deployed during the experiment, this experiment represented a unique opportunity to study and quantify the abiotic processes of dissolution and adsorption of DFe occurring from/at mineral particle surfaces.

\section{Model description}

The DUNE experiment is simulated in a one-dimensional model representing the upper $15 \mathrm{~m}$ of the water column. The water column is divided into 30 layers with a uniform water layer thickness of $0.5 \mathrm{~m}$. The model consists of an ecosystem model coupled to a physical model (Sects. 3.1-3.4, model equations are presented in the Appendix). Data measured in the mesocosms before dust addition are used to initialise the model. The temporal evolution of state variables is calculated at a time step of $10 \mathrm{~min}$. The model is spun up for $48 \mathrm{~h}$ and further integrated for the entire experiment period from 11 to 18 June 2008. Dust particles are added from 10:00 to 11:00 on 11 June as a surface flux of $1.4 \times 10^{-6} \mathrm{~kg} \mathrm{~m}^{-2} \mathrm{~s}^{-1}$, corresponding to a total addition of $41.5 \mathrm{~g}$ dust particles.

\subsection{Physical model}

The physical part of the model is the General Ocean Turbulence Model (GOTM, Umlauf and Burchard, 2005, www. gotm.net) which provides the vertical mixing and advection for a given forcing by wind, heat and freshwater fluxes at the surface. Forcing data for the DUNE site are 6-hourly fluxes derived from the Japan Meteorological Agency Climate Data Assimilation System (JCDAS) (Onogi et al., 2007). A $k$ $\epsilon$ turbulence closure is used to calculate turbulence kinetic energy. Vertical advection and sinking of biogeochemical quantities are calculated using a third-order scheme with flux limiter (Burchard and Umlauf, 2005).

\subsection{Ecosystem model}

The focus of this study are the processes controlling DFe change during the dust addition experiment, not the impact of the additional iron on diverse biological activities. Therefore, the ecosystem responses to dust addition are described in a very simple NPZD-type model. There are two nutrient pools - dissolved inorganic phosphorus (DIP) and dissolved iron (DFe), a phytoplankton (PHY), a zooplankton (ZOO) and detritus (DET) which is divided into two size classes (Fig. 1, for the classification of detritus see Table 2). The

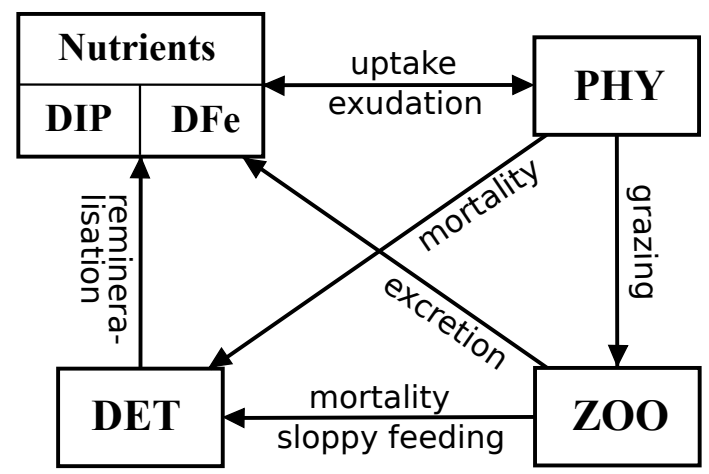

Fig. 1. Ecosystem model.

model is based on P, because the low surface DIP concentration at the DUNE site (Pulido-Villena et al., 2010) suggests that primary production there is P-limited rather than $\mathrm{N}$-limited. We introduced a variable Fe:P ratio for each component, so that the effect of $\mathrm{P}$ and $\mathrm{Fe}$ added with dust particles on the ecosystem can be simulated separately. The flux description of the model and the parameter values are mostly taken from Ye et al. (2009), and the half saturation constant of P uptake $\left(K_{\mathrm{p}}\right)$ is modified from Sohm and Capone (2006), reproducing the observed temporal evolution of DIP and Chl at the DUNE site (Table 1). The surface input of $\mathrm{P}$ by dust addition is $\sim 230 \mu \mathrm{mol}$, calculated with a $\mathrm{P}$ content in dust particles of $0.05 \%$ (Guieu et al., 2010) and a solubility of $35 \%$ (Pulido-Villena et al., 2010).

\subsection{Particle dynamics}

The size distribution of dust particles used in the experiment can be described with three log-normal modes of roughly the same total volume ( $\sim 33 \%)$. Particles having the median volume of each mode are about 1.6, 6.2 and $12 \mu \mathrm{m}$ in diameter, respectively (Guieu et al., 2010). In order to keep a certain model simplicity and at the same time consider the different behaviour of particle size classes in surface adsorption and sinking, we modelled two size classes of dust particles with a mean diameter of 2 and $10 \mu \mathrm{m}\left(P_{\mathrm{d}}\right.$ and $\left.P_{\mathrm{s}}\right)$, representing the smallest mode and the two larger modes together. $33 \%$ of the dust particles is added as surface flux into $P_{\mathrm{d}}$ during the dust addition, and $67 \%$ into $P_{\mathrm{s}}$.

The mean settling velocity of dust particles, calculated from the temporal variations of measured PAl in the upper $5 \mathrm{~m}$, is much higher than that estimated from Stoke's law using the size distribution of the added dust particles (Guieu et al., 2010b). This strongly suggests the importance of particle aggregation. We therefore took into account particle aggregation in our model and introduced another particle class $\left(P_{1}\right)$ for large aggregates which have a mean diameter of $50 \mu \mathrm{m}$.

Sinking organic matter in the model has two classes with comparable size to $P_{\mathrm{S}}$ and $P_{1}$, respectively: $\mathrm{D}_{\mathrm{s}}$ representing small detritus and the organic part of small aggregates and 
Table 1. Parameters in the biological model. Source of parameter values are shown as footnotes; other parameters are optimised for the North Atlantic by Schartau and Oschlies (2003a,b).

\begin{tabular}{|c|c|c|c|}
\hline Parameters & Symbol & Unit & Value \\
\hline maximum growth rate of phytoplankton & $\mu_{\max }$ & $\mathrm{d}^{-1}$ & 0.27 \\
\hline phytoplankton mortality & $\gamma_{\mathrm{p}}$ & $\mathrm{d}^{-1}$ & 0.04 \\
\hline initial slope P-I curve & $\alpha$ & $\mathrm{m}^{2} \mathrm{~W}^{-1} \mathrm{~d}^{-1}$ & 0.256 \\
\hline phosphate half-saturation constant & $K_{\mathrm{P}}$ & $\mathrm{mmol} \mathrm{m}^{-3}$ & $0.01^{\mathrm{a}}$ \\
\hline iron half-saturation constant & $K_{\mathrm{Fe}}$ & $\mu \mathrm{mol} \mathrm{m}{ }^{-3}$ & 0.2 \\
\hline phytoplankton aggregation rate & $\gamma_{\mathrm{p}^{2}}$ & $\left(\mathrm{mmol} \mathrm{m} \mathrm{m}^{-3}\right)^{-1} \mathrm{~d}^{-1}$ & 0.025 \\
\hline maximum grazing rate & $g_{\max }$ & $\mathrm{d}^{-1}$ & 1.575 \\
\hline prey capture rate & $\epsilon$ & $\left(\mathrm{mmol} \mathrm{m} \mathrm{m}^{-3}\right)^{-1} \mathrm{~d}^{-1}$ & 1.6 \\
\hline assimilation efficiency & $\gamma_{\mathrm{za}}$ & - & 0.925 \\
\hline excretion & $\gamma_{\mathrm{zb}}$ & $\mathrm{d}^{-1}$ & 0.01 \\
\hline quadratic mortality of zooplankton & $\gamma_{z^{2}}$ & $\left(\mathrm{mmol} \mathrm{m}{ }^{-3}\right)^{-1} \mathrm{~d}^{-1}$ & 0.34 \\
\hline detritus remineralisation & $\gamma_{\mathrm{d}}$ & $\mathrm{d}^{-1}$ & 0.048 \\
\hline sinking velocity of fine dust particles & $w_{\mathrm{d}}$ & $\mathrm{md}^{-1}$ & $0.2^{\mathrm{b}}$ \\
\hline $\begin{array}{l}\text { sinking velocity of coarse dust particles, } \\
\text { small detritus and small aggregates }\end{array}$ & $w_{\mathrm{s}}$ & $\mathrm{m} \mathrm{d}^{-1}$ & $5^{b}$ \\
\hline $\begin{array}{l}\text { sinking velocity of large detritus } \\
\text { and large aggregates }\end{array}$ & $w_{1}$ & $\mathrm{md}^{-1}$ & $50^{\mathrm{b}}$ \\
\hline coefficient for temperature function & $C_{\text {ref }}$ & - & 1.066 \\
\hline PAR:short-wave irradiance ratio & $f_{\mathrm{PAR}}$ & - & 0.43 \\
\hline attenuation due to chlorophyll & $\kappa$ & $\mathrm{m}^{2}(\mathrm{mmolN})^{-1}$ & 0.03 \\
\hline maximum Fe:P ratio in organic matter & $Q_{\mathrm{Fe}}^{\max }$ & $\mu \mathrm{mol} \mathrm{m} \mathrm{m}^{-3}\left(\mathrm{mmol} \mathrm{m}^{-3}\right)^{-1}$ & $0.53^{\mathrm{c}}$ \\
\hline minimum Fe:P ratio in organic matter & $Q_{\mathrm{Fe}}^{\min }$ & $\mu \mathrm{mol} \mathrm{m} \mathrm{m}^{-3}\left(\mathrm{mmol} \mathrm{m}^{-3}\right)^{-1}$ & $0.11^{\mathrm{c}}$ \\
\hline mass:P ratio in organic matter & $r_{\mathrm{m}: \mathrm{P}}$ & $\mathrm{g} \mathrm{mol}^{-1}$ & $2.5 \times 10^{+3 \mathrm{~d}}$ \\
\hline
\end{tabular}

a Modified from Sohm and Capone (2006).

b Calculated from Stoke's Law.

c Calculated from the Fe:N ratio by Sunda and Huntsman (1995) and the Redfield N:P ratio.

$\mathrm{d}$ Calculated with the Redfield C:P ratio and the assumption that $1 \mathrm{~g} \mathrm{C}$ corresponds $2 \mathrm{~g}$ mass.

Table 2. Particle classification in the model.

\begin{tabular}{llrr}
\hline Particles & Symbol & Diameter $(\mu \mathrm{m})$ & Settling velocity $\left(\mathrm{m} \mathrm{d}^{-1}\right)$ \\
\hline fine dust particles & $P_{\mathrm{d}}$ & 2 & 0.2 \\
coarse dust particles and inorganic part of small aggregates & $P_{\mathrm{S}}$ & 10 & 5 \\
small detritus and organic part of small aggregates & $\mathrm{D}_{\mathrm{s}}$ & 10 & 5 \\
inorganic part of large aggregates & $P_{1}$ & 50 & 50 \\
large detritus and organic part of large aggregates & $\mathrm{D}_{1}$ & 50 & 50 \\
\hline
\end{tabular}

$\mathrm{D}_{1}$ representing large detritus and the organic part of large aggregates. Table 2 gives an overview of modelled particle classes, their size and settling velocities estimated from Stoke's law.

\subsection{Chemical model}

The concentration of DFe and PFe were measured in the water column of the mesocosms and the PFe flux was determined in the sediment traps (Wagener et al., 2010). We simplified the Fe speciation model of Ye et al. (2009) based on these two measured forms of $\mathrm{Fe}$ to avoid unnecessary speculation on the various Fe species which can not be compared to observations. There are four main $\mathrm{Fe}$ species in this model: the dissolvable fraction of iron in dust particles $\left(\mathrm{Fe}_{\text {dust }}\right)$, iron inside the organic matter $\mathrm{Fe}_{\text {org }}$, dissolved iron (DFe), including soluble and colloidal iron, and iron adsorbed on sinking particles $\left(\mathrm{PFe}_{\text {sorp }}\right)$ (Fig. 2). $\mathrm{PFe}_{\text {sorp }}$ differs from the measured $\mathrm{PFe}$ which includes not only iron adsorbed on particles but also iron inside sinking particles. Three subclasses of $\mathrm{PFe}_{\text {sorp }}\left(\mathrm{PFe}_{\mathrm{d}}, \mathrm{PFe}_{\mathrm{s}}\right.$ and $\left.\mathrm{PFe}_{1}\right)$ are considered in the model due to adsorption on particles of different size classes. Iron adsorbed on the surface of organic sinking particles $\left(D_{s}\right.$ and $\mathrm{D}_{1}$ ) is also included in $\mathrm{PFe}_{\mathrm{S}}$ and $\mathrm{PFe}_{1}$. Four processes supply DFe (Fig. 2): (1) dissolution from added dust particles, (2) iron release by remineralisation of organic matter, (3) desorption and (4) photoreduction of $\mathrm{PFe}_{\text {sorp }}$. Biological uptake and adsorption onto sinking particles remove iron from the dissolved pool. Parameter values are listed in Table 3. 


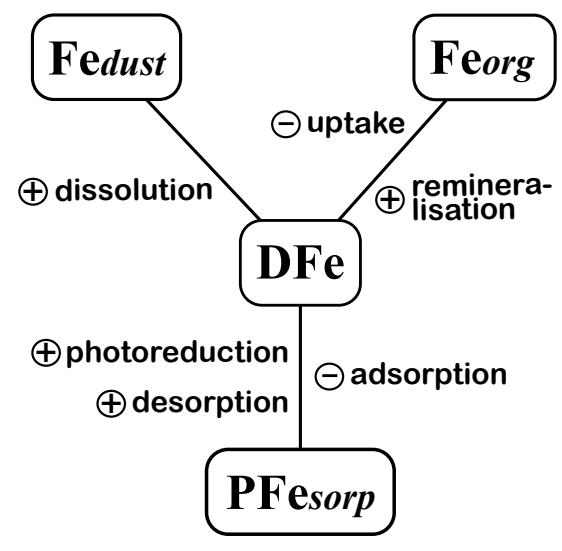

Fig. 2. Chemical model of iron. Processes supplying DFe haven a sign of + and those removing DFe a sign of - .

We considered an iron input by dust addition of $\sim 1 \mathrm{mg}$, based on an $\mathrm{Fe}$ content in the added dust particles of $2.31 \%$ (Guieu et al., 2010) and a solubility of $0.1 \%$ (Wagener et al., 2010). In lab studies, increasing leaching time results in increases in Fe dissolution (Bonnet and Guieu, 2004) indicating that $\mathrm{Fe}$ dissolution is a multi-timescale process. Wagener et al. (2008) studied the dissolution kinetics of Fe from dust particles and supposed one fast and one slowly dissolvable iron fraction. We introduced a dissolution timescale of 3 days into our model which represents the fast dissolution of iron. Surface iron flux by dust addition is divided into two dissolvable iron pools which are proportional to the two size-fractions of dust particles $\left(P_{\mathrm{d}}\right.$ and $\left.P_{\mathrm{S}}\right)$. From these two pools, iron is released to the DFe pool with a time constant of 3 days. The difference to a run with instantaneous dissolution of iron is discussed in Sect. 4.3.3.

The adsorption rate of iron onto particles is proportional to particle surface. Since in lab studies, the adsorption rate of iron is often determined in relationship to particle mass, we scaled the mass-related adsorption rate constants with the surface:volume ratios of the modelled particle size classes, assuming that all the particles are approximately spherical.

The observed DFe decrease of $\sim 1 \mu \mathrm{mol} \mathrm{m}^{-3}$ immediately following the dust addition indicates strong removal processes of DFe by sinking particles. The adsorption of DFe onto particles is described in the model as a function of $\mathrm{DFe}$ and particle concentration. Because DFe in the model is the sum of colloidal and soluble iron, both adsorption of colloidal and soluble iron are taken into account in this way. Different adsorption rate constants were tested in a sensitivity study for reproducing the observed DFe concentrations (Sect. 4.3.4).

\section{Results}

To obtain realistic physical conditions for biological and chemical processes, we compared at first modelled temperature and mixing to measurements during DUNE. Model runs without and with dust surface flux simulate the average situation in CONTROL-meso and DUST-meso, respectively.

\subsection{Physical conditions}

During the DUNE experiment, seawater temperatures ranged from $18-21.5^{\circ} \mathrm{C}$. The vertical temperature gradient was highest on the day before the dust addition. The diurnal variability of temperature was relatively weak and the water was well mixed during the night. Towards the end of the experiment, a stronger temperature gradient was built up again (Fig. 3a). Using the meteorological forcing data from JCDAS (Sect. 3.1), the modelled temperature ranges from 18.5-22.5 ${ }^{\circ} \mathrm{C}$ (Fig. 3b). A temporal evolution of temperature similar to the observation is found in the model: in the beginning of the experiment, high surface temperature and larger vertical gradient cause stronger stratification. The gradient declines with cooling of surface waters and warming of subsurface waters within the first 3 days. From 14 June on, water is mixed completely in the upper $15 \mathrm{~m}$. Surface temperature increases during the last 2 days of the experiment and a clear vertical gradient is built up again. Yet, the modelled vertical temperature gradient is clearly higher than that observed, particularly during the first days of the experiment. This produces a stronger stratification. One possible explanation could be that the wind forcing is too weak, because the reanalysis data lacks small-scale effects. The experimental site is relatively close to land and one would expect a strong daily cycle of winds driven by the different heat capacities of land and sea surface. Increasing the wind speed in the forcing data with a factor of two in a test run (not shown), modelled stratification becomes closer to the observations. Using local observations of wind strength as forcing in future work could improve the model-data agreement.

\subsection{Simulation of CONTROL-meso}

\subsubsection{Chlorophyll}

Measured Chl in CONTROL-meso varied between 0.08$0.15 \mathrm{mg} \mathrm{m}^{-3}$. We calculated Chl from modelled phytoplankton phosphorus by using a mean $\mathrm{Chl}: \mathrm{C}$ weight ratio of 1:60 for typical phytoplankton and the molar Redfield C:P ratio of $106: 1$. The calculated Chl varies from $0.09-0.13 \mathrm{mg} \mathrm{m}^{-3}$ (Fig. 4a), in the range of the observations.

\subsubsection{Inorganic particles}

Particulate aluminium (PAl) has been measured at $5 \mathrm{~m}$ depth in CONTROL-meso. We calculated concentrations of inorganic particles using an average $\mathrm{Al}$ content of $7.7 \%$ for 
Table 3. Parameters in the chemical model.

\begin{tabular}{|c|c|c|c|}
\hline Parameters & Symbol & Unit & Value \\
\hline solubility of atmospheric iron & $r_{\mathrm{sol}}$ & $\%$ & $0.1^{\mathrm{a}}$ \\
\hline iron content of dust particles & $r_{\mathrm{Fe}}$ & $\%$ & $2.3^{\mathrm{a}}$ \\
\hline iron dissolution rate & $k_{\text {rel }}$ & $\mathrm{d}^{-1}$ & $3^{b}$ \\
\hline DFe adsorption rate & $k_{\text {sorp }}$ & $\mathrm{kg}^{-1} \mathrm{~m}^{3} \mathrm{~d}^{-1}$ & $150^{\mathrm{c}}$ \\
\hline $\begin{array}{l}\text { scaling factor of the surface-related } \\
\text { adsorption rate for } P_{\mathrm{d}}\end{array}$ & $R_{\text {surf }}^{\mathrm{d}}$ & - & $5^{\mathrm{d}}$ \\
\hline $\begin{array}{l}\text { scaling factor of the surface-related } \\
\text { adsorption rate for } P_{\mathrm{S}}\end{array}$ & $R_{\text {surf }}^{\mathrm{s}}$ & - & $1^{\mathrm{d}}$ \\
\hline $\begin{array}{l}\text { scaling factor of the surface-related } \\
\text { adsorption rate for } P_{1}\end{array}$ & $R_{\text {surf }}^{1}$ & - & $0.2^{\mathrm{d}}$ \\
\hline reference irradiance & $I_{\text {ref }}$ & $\mu \mathrm{Em}^{-2} \mathrm{~s}^{-1}$ & 1978 \\
\hline $\mathrm{PFe}$ photoreduction rate & $k_{\mathrm{ph}}$ & $\mathrm{d}^{-1}$ & $20.2^{\mathrm{e}}$ \\
\hline $\mathrm{PFe}$ redissolution rate & $k_{\mathrm{pd}}$ & $d^{-1}$ & $0.015^{\mathrm{f}}$ \\
\hline coagulation rate & $k_{\text {coag } 1}$ & $\left(\mathrm{~kg} \mathrm{l}^{-1}\right)^{-1} \mathrm{~s}^{-1}$ & $4.5^{\mathrm{g}}$ \\
\hline coagulation rate & $k_{\text {coag2 }}$ & $\left(\mathrm{kg} \mathrm{l}^{-1}\right)^{-1} \mathrm{~s}^{-1}$ & $11^{\mathrm{g}}$ \\
\hline coagulation rate & $k_{\text {coag } 3}$ & $\left(\mathrm{~kg} \mathrm{l}^{-1}\right)^{-1} \mathrm{~s}^{-1}$ & $15^{\mathrm{g}}$ \\
\hline coagulation rate & $k_{\text {coag } 4}$ & $\left(\mathrm{~kg} \mathrm{l}^{-1}\right)^{-1} \mathrm{~s}^{-1}$ & $13^{\mathrm{g}}$ \\
\hline
\end{tabular}

a Wagener et al. (2010).

b Wagener et al. (2008).

${ }^{c}$ Estimated in the sensitivity study in Sect. 4.3.4.

$\mathrm{d}$ Calculated from the size of modelled particles assuming all the particles are spherical.

e Johnson et al. (1994).

${ }^{\mathrm{f}}$ Sensitivity study in Ye et al. (2009).

$\mathrm{g}$ Adapted from Ye et al. (2009).
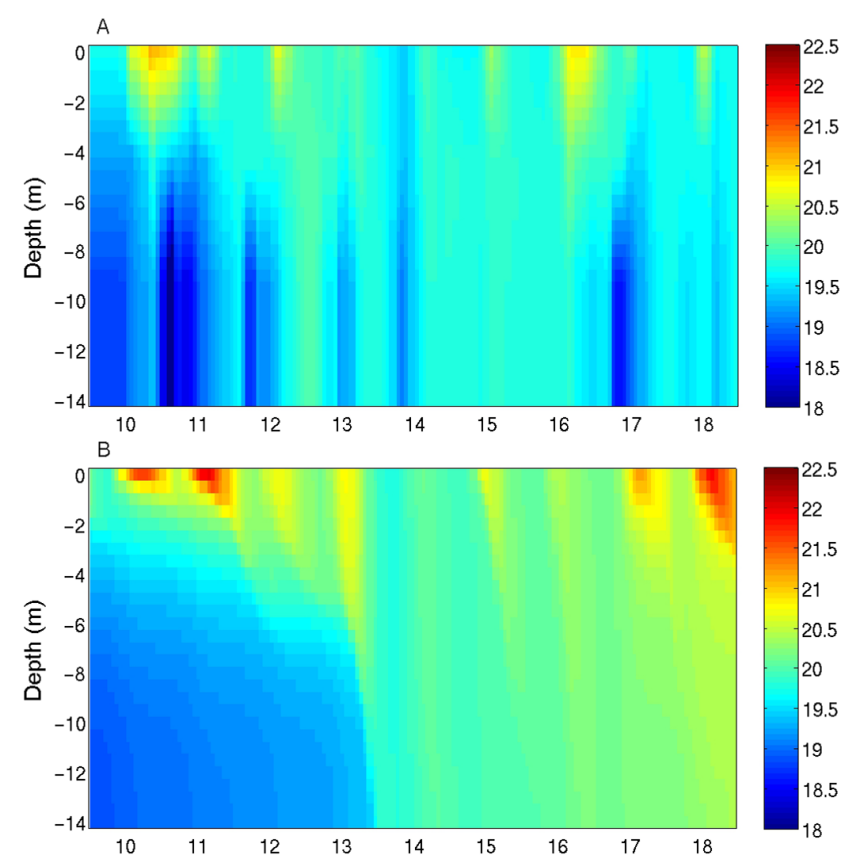

Fig. 3. Observed (A) and modelled (B) temperature $\left({ }^{\circ} \mathrm{C}\right)$ during the DUNE experiment.
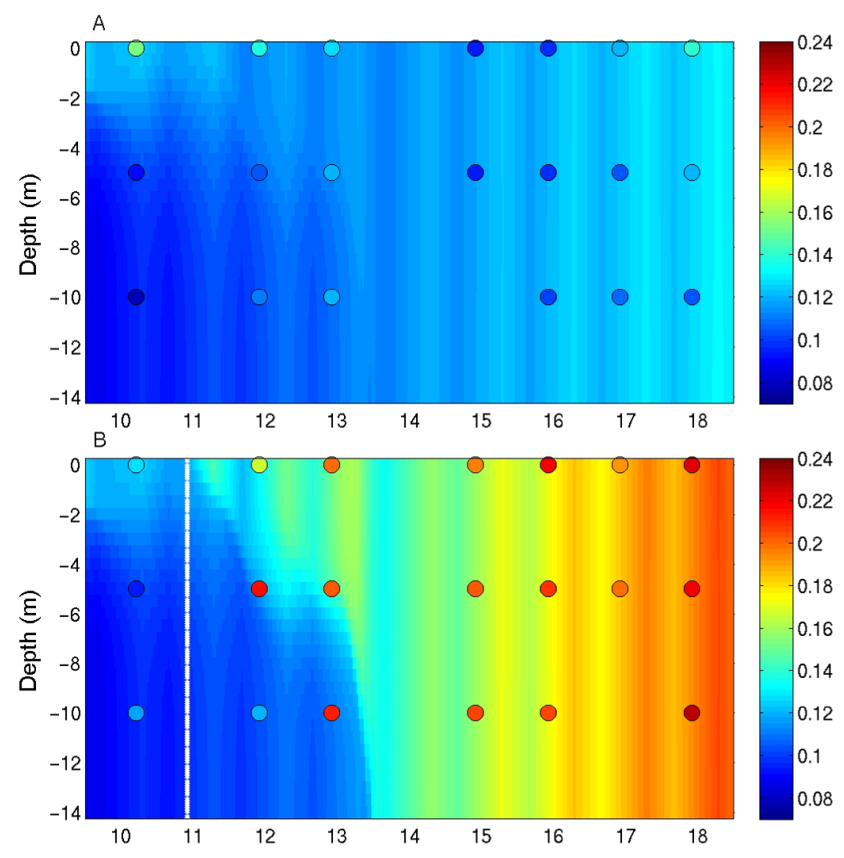

Fig. 4. Modelled Chl concentration $\left(\mathrm{mg} \mathrm{m}^{-3}\right)$ in CONTROLmeso (A) and DUST-meso (B). Coloured dots are the measured Chl concentrations. The white bar shows the time of dust addition. 

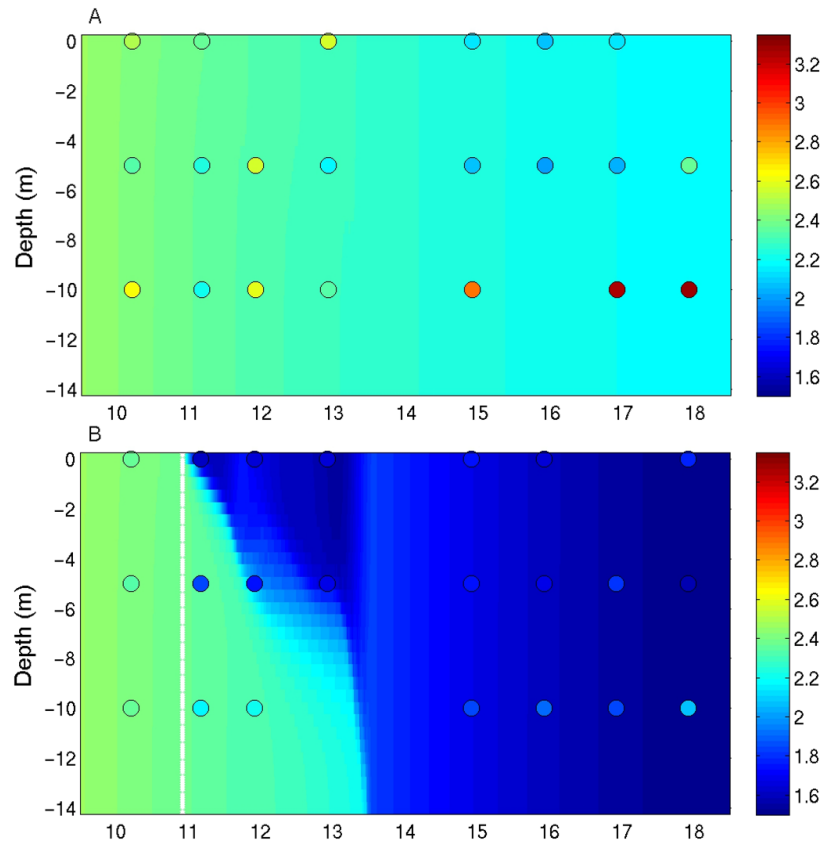

Fig. 5. Modelled DFe concentration $\left(\mu \mathrm{mol} \mathrm{m}{ }^{-3}\right)$ in CONTROLmeso (A) and DUST-meso (B). Coloured dots are the measured DFe concentrations. The white bar shows the time of dust addition.

continental crust (Wedepohl, 1995), assuming that inorganic particles in CONTROL-meso were from typical average lithogenic sources. Concentrations of inorganic particles are in the order of $10^{-8} \mathrm{~kg} \mathrm{~m}^{-3}$, decreasing slowly with time. Similarly, we calculated exported particle mass from exported PAl which was measured every 2 days in the sediment traps at the bottom of the mesocosms. Fluxes of particle export $\left(\mathrm{mg} \mathrm{m}^{-2} \mathrm{~d}^{-1}\right)$ through the area of the mesocosms $\left(4.15 \mathrm{~m}^{2}\right)$ are averaged for every 2 days. The particle export shows a relatively high variability both within and between the mesocosms (from $2-25 \mathrm{mg} \mathrm{m}^{-2} \mathrm{~d}^{-1}$ ) and different temporal patterns in the three mesocosms (Table 4). The mean export of CONTROL-meso varies with time from 4$14 \mathrm{mg} \mathrm{m}^{-2} \mathrm{~d}^{-1}$.

The observed particle concentrations decreased slowly with time, indicating that the main part of sinking particles in CONTROL-meso is very small. We thus used the observed concentration at $5 \mathrm{~m}$ as the initial concentration of the smallest particle class $\left(P_{\mathrm{d}}\right)$ throughout the water column. With the assumption of a settling velocity of $0.2 \mathrm{~m} \mathrm{~d}^{-1}$ for $P_{\mathrm{d}}$ (Table 2), the model-produced concentration of total inorganic particles at $5 \mathrm{~m}$ is in the same order as the measured data. Particle export flux averaged over 2 days varies between 7 $12 \mathrm{mg} \mathrm{m}^{-2} \mathrm{~d}^{-1}$ (Table 4), in good agreement with the observed mean.
Table 4. Measured and modelled export flux of inorganic particles ( $\mathrm{mg} \mathrm{m}^{-2} \mathrm{~d}^{-1}$ ) under control conditions, calculated assuming an $\mathrm{Al}$ content of $7.7 \%$. C1-C3 stand for the triplicate CONTROL-meso, $\mathrm{C}_{\mathrm{ave}}$ for the mean of $\mathrm{C} 1-\mathrm{C} 3$ and $\mathrm{M}$ for model results. Numbers are averaged fluxes in the time periods after dust addition in DUSTmeso.

\begin{tabular}{lrrrr}
\hline & $24 \mathrm{~h}^{*}$ & $72 \mathrm{~h}$ & $120 \mathrm{~h}$ & $168 \mathrm{~h}$ \\
\hline $\mathrm{C} 1$ & 9.7 & 6.3 & 1.9 & 5.5 \\
$\mathrm{C} 2$ & 2.0 & 9.9 & 13.0 & 2.8 \\
$\mathrm{C} 3$ & 5.9 & 24.6 & 1.9 & $\mathrm{n} / \mathrm{a}$ \\
$\mathrm{C}_{\text {ave }}$ & 5.9 & 13.6 & 5.6 & 4.2 \\
$\mathrm{M}$ & 11.8 & 8.8 & 7.5 & 7.3 \\
\hline
\end{tabular}

* Exported mass from $24 \mathrm{~h}$ before to $24 \mathrm{~h}$ after the addition.

Table 5. Measured and modelled export flux of $\mathrm{Fe}\left(\mathrm{mg} \mathrm{m}^{-2} \mathrm{~d}^{-1}\right)$ under control conditions. $\mathrm{C} 1-\mathrm{C} 3$ stand for the triplicate CONTROL-meso, $\mathrm{C}_{\mathrm{ave}}$ for the mean of $\mathrm{C} 1-\mathrm{C} 3$ and $\mathrm{M}$ for model results. Numbers are averaged fluxes in the time periods after dust addition in DUST-meso.

\begin{tabular}{lrrrr}
\hline & $24 \mathrm{~h}^{*}$ & $72 \mathrm{~h}$ & $120 \mathrm{~h}$ & $168 \mathrm{~h}$ \\
\hline $\mathrm{C} 1$ & 0.4 & 0.3 & 0.1 & 0.2 \\
$\mathrm{C} 2$ & 0.1 & 0.4 & 0.5 & 0.1 \\
$\mathrm{C} 3$ & 0.3 & 1.0 & 0.1 & $\mathrm{n} / \mathrm{a}$ \\
$\mathrm{C}_{\mathrm{ave}}$ & 0.3 & 0.6 & 0.2 & 0.2 \\
$\mathrm{M}$ & 0.3 & 0.3 & 0.2 & 0.2 \\
\hline
\end{tabular}

* Exported mass from $24 \mathrm{~h}$ before to $24 \mathrm{~h}$ after the addition.

\subsubsection{Iron}

Observed DFe was relatively constant around $2.5 \mu \mathrm{mol} \mathrm{m} \mathrm{m}^{-3}$ with a decrease to $2 \mu \mathrm{mol} \mathrm{m} \mathrm{m}^{-3}$ in the upper $5 \mathrm{~m}$ and an increase to $3.5 \mu \mathrm{mol} \mathrm{m}{ }^{-3}$ at $10 \mathrm{~m}$ depth (Fig. 5a). The iron adsorption rate constants are estimated in a sensitivity study (Sect. 4.3.4), mainly based on the change of DFe concentrations in DUST-meso. In CONTROL-meso, the different adsorption rate constants tested in the sensitivity study do not influence DFe concentration to a significant extent, because the concentration of sinking particles is low. DFe in the model decreases with time from 2.5 to $2.3 \mu \mathrm{mol} \mathrm{m}^{-3}$ caused by adsorptive removal. Although DFe shows a smaller variability than in the observations, its concentrations represent well the average condition in CONTROL-meso. Modelled export of total $\mathrm{PFe}$ which includes iron inside sinking particles and iron adsorbed on particles, varies between 0.2$0.3 \mathrm{mg} \mathrm{m}^{-2} \mathrm{~d}^{-1}$ which is close to the mean of the three mesocosms (Table 5). 


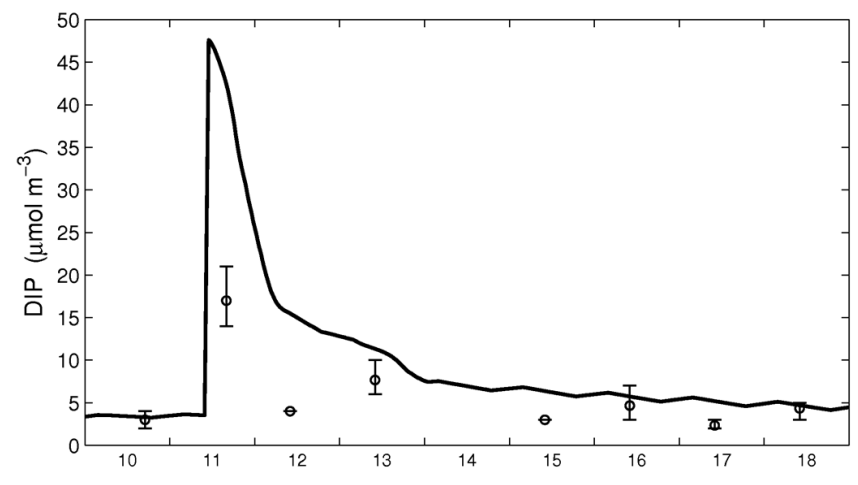

Fig. 6. Modelled (curve) and measured (circle) surface DIP concentration in DUST-meso. Error bars show the total range of measured data.

\subsection{Simulation of DUST-meso}

\subsubsection{Phosphorus and chlorophyll evolution}

Six hours after the dust addition, surface DIP in all three DUST-meso increased from $4 \pm 1$ to $17 \pm 4 \mu \mathrm{mol} \mathrm{m}{ }^{-3}$. No increase was observed at 5 and $10 \mathrm{~m}$ depth (PulidoVillena et al., 2010). The modelled DIP concentration is about $3-5 \mu \mathrm{mol} \mathrm{m}{ }^{-3}$ before dust addition and is elevated to $\sim 50 \mu \mathrm{mol} \mathrm{m}^{-3}$ at surface immediately after DUST addition (Fig. 6). After that, DIP falls back to the initial concentration within $72 \mathrm{~h}$ caused by strong phytoplankton uptake. The modelled surface DIP at $6 \mathrm{~h}$ after dust addition is about $42 \mu \mathrm{mol} \mathrm{m}{ }^{-3}$, more than twice as high as the observations. This is caused by the modelled stronger stratification in the first days of the experiment, preventing mixing down of DIP supplied by dust addition (Sect. 4.1). The decline of DIP after its maximum is therefore also a little slower in the model than observed.

Before the dust addition at 10:00 on 11 June, modelled Chl varies from 0.12 at the surface to $0.09 \mathrm{mg} \mathrm{m}^{-3}$ at $15 \mathrm{~m}$ depth with a clear diurnal pattern (identical to CONTROL-meso). Immediately after the dust addition, Chl concentration starts to increase and reaches a maximum of $0.2 \mathrm{mg} \mathrm{m}^{-3}$ on the last day of the experiment (Fig. 4b). The growth limitation by $\mathrm{P}$ in the model is described with a Michaelis-Menten term (Eq. A7). This term increases from 0.2 before to 0.9 shortly after the dust addition and drops back below 0.6 within $24 \mathrm{~h}$. The limitation by $\mathrm{Fe}$ is described with the internal $\mathrm{Fe}: \mathrm{P}$ ratio (Eq. A6). In contrast to the P-limitation term, the Felimitation term falls with the dust addition from 0.93 to 0.88 and remains at this level until the end of the experiment. As the actual growth rate is determined by the smaller of these two terms and the P-limitation term is almost always smaller than that of $\mathrm{Fe}$, the $\mathrm{Chl}$ increase in the model is stimulated by DIP input, as suggested by Pulido-Villena et al. (2010).

The temporal evolution of $\mathrm{Chl}$ is also consistent with the observation of a doubling at the end of the experiment (Guieu

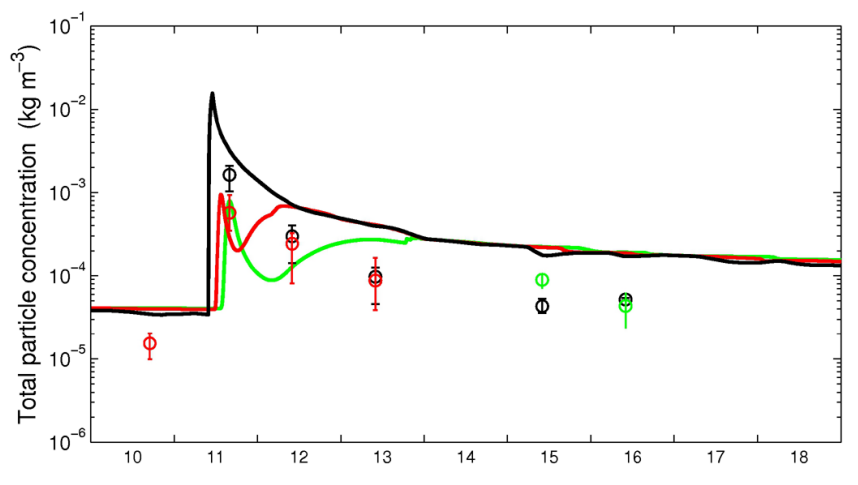

Fig. 7. Modelled (curve) and measured (circle) total inorganic particle concentration in DUST-meso at different depths on a logarithmic scale: $0 \mathrm{~m}$ (black), $5 \mathrm{~m}$ (red) and $10 \mathrm{~m}$ (green). Error bars show the total range of measured data.

et al., 2011; Guieu, 2009). However, the observed Chl concentrations reached $0.2 \mathrm{mg} \mathrm{m}^{-3}$ already $48 \mathrm{~h}$ after the addition and remained at this level until the end of the experiment. This suggests that a faster growth was induced by DIP addition and that some loss factors, e.g. grazing, balanced the growth of phytoplankton during the last days of the experiment. The modelled stronger stratification in the beginning of the experiment might delay the DIP supply for the entire water column and thus delay the increase of phytoplankton. $\mathrm{A}$ better reproduction of the observed $\mathrm{Chl}$ could be obtained by changing biological parameters in the model, if direct observations of phytoplankton community composition, grazers or phytoplankton mortality are available. For the focus of this study - the Fe cycling, this biological model is sufficient. Iron in organic matter is only a negligible fraction of the entire budget. Before the dust addition, the organic $\mathrm{Fe}$ fraction in the water column is about $0.1 \%$ (the insoluble part of iron inside the dust particles is not considered). Immediately after the addition, it falls to $0.05 \%$ and increases to the end of the experiment to $0.2 \%$. Moreover, the main removal process of DFe is particle adsorption and biological uptake is $2-4$ orders of magnitude lower than the adsorptive loss.

\subsubsection{Particle dynamics}

In DUST-meso, particle concentration has been measured at 0,5 and $10 \mathrm{~m}$ depth. The model reproduces the particle concentration at $0 \mathrm{~m}$ well with a sharp increase to a maximum immediately after addition and a quick decrease within the first $6 \mathrm{~h}$ (Fig. 7). The decrease slows down with time, because sinking particles become more and more dominated by the fine dust particles $\left(P_{\mathrm{d}}\right)$.

At $5 \mathrm{~m}$ depth, modelled particle concentration shows two peaks around $10^{-3} \mathrm{~kg} \mathrm{~m}^{-3}$ : a first one at $3 \mathrm{~h}$ after addition and a second one after $24 \mathrm{~h}$. The first peak is a result of $P_{\mathrm{S}}$ aggregation in surface water and the subsequent sinking of large aggregates. The second peak is due to sinking of 
Table 6. Measured and modelled export flux of inorganic particles $\left(\mathrm{g} \mathrm{m}^{-2} \mathrm{~d}^{-1}\right)$ under dust addition, calculated assuming an $\mathrm{Al}$ content of $4 \%$. D1-D3 stand for the triplicate mesocosms with dust addition, $\mathrm{D}_{\text {ave }}$ for the mean of D1-D3 and $\mathrm{M}$ for model results. Numbers are averaged fluxes in the time periods after dust addition.

\begin{tabular}{lrrrr}
\hline & $24 \mathrm{~h}^{*}$ & $72 \mathrm{~h}$ & $120 \mathrm{~h}$ & $168 \mathrm{~h}$ \\
\hline D1 & 0.6 & 1.7 & 0.3 & 0.1 \\
D2 & 0.5 & 1.2 & 0.8 & 0.1 \\
D3 & 0.9 & 0.9 & 0.5 & 0.1 \\
Dave & 0.6 & 1.3 & 0.5 & 0.1 \\
M & 2.3 & 0.9 & 0.5 & 0.2 \\
\hline
\end{tabular}

* Exported mass from $24 \mathrm{~h}$ before to $24 \mathrm{~h}$ after the addition.

$P_{\mathrm{S}}$ itself which takes one day from the surface to $5 \mathrm{~m}$ depth. Particle concentration decreases slowly after that, because $P_{\mathrm{d}}$ also dominates at this depth after $P_{\mathrm{s}}$ sinks out. The first peak is in good agreement with the observations, while the second one is not found in the measurements. This may be due to the limited time resolution in the data.

At $10 \mathrm{~m}$ depth, a first peak occurs later than at $5 \mathrm{~m}$ because of longer sinking. After that, particle concentration increases slowly for about one day which is mainly caused by sinking of $P_{\mathrm{s}}$ from surface waters. In the last days of the experiment, the particle concentration is low and decreases slowly with time, because fine dust particles dominate and sink slowly. Particle concentration at $10 \mathrm{~m}$ depth is basically in the same magnitude as measured. However, like at the other depths above, modelled particle concentration from the 3rd day to the end of the experiment is $2-3$ fold as high as the average of the triplicate mesocosms. Two reasons could explain the difference between model and measurement: (1) a water layer with high particle concentration could have been missed due to limited sampling resolution (Wagener et al., 2010); and (2) particles might have adhered to mesocosms (see below).

Like in the comparison with control conditions, we also calculated the mean export of inorganic particles for every 2 days (Table 6). The modelled export in the first $24 \mathrm{~h}$ after the dust addition is obviously higher than the measured mean, whereas the later export fluxes are close to the observations. The high export within the first $24 \mathrm{~h}$ in the model is caused by the aggregation of $P_{\mathrm{S}}$ which initially after the dust addition has a very high concentration close to the surface. This must have happened, since otherwise, particles could not be exported out of the upper $10 \mathrm{~m}$ within the first $48 \mathrm{~h}$ as observed by Wagener et al. (2010).

Several factors could lead to the lower particle export in the measurement. Guieu et al. (2010) mentioned that a fraction of particles could have been lost during exchange of the traps or adhered to the conical bottom of mesocosms. The sticking of particles on the mesocosm walls and in the conical part of the mesocosms could play a role for both reduced concentration in the water column and lower sedimentation.

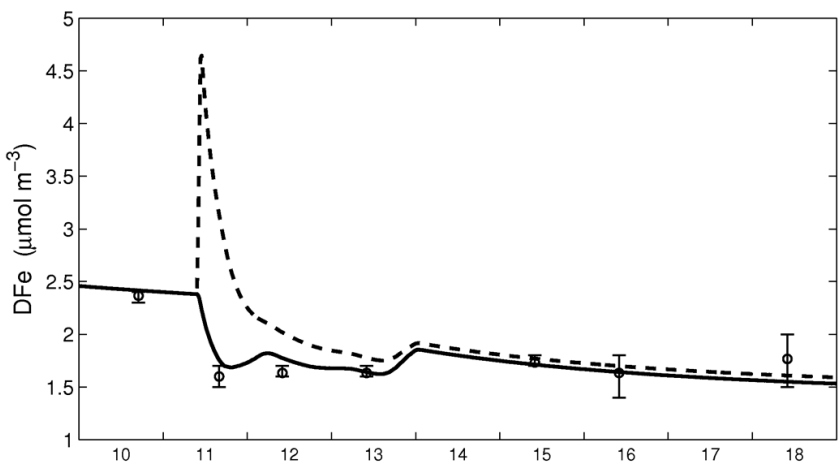

Fig. 8. Sensitivity study with respect to iron dissolution timescale. Solid: surface DFe using a timescale of 3 days; dashed: surface DFe using an instantaneous dissolution. Circles are measured surface DFe concentrations. Error bars show the total range of measured data.

The shape of the mesocosm bottom with reducing diameter may have enlarged the sticking effect. Because of the small surface:volume ratio of the mesocosms, the adsorption on mesocosm walls could be negligible (Wagener et al., 2010). A similar difference between model and observation is also found in concentration and export of PFe (Sect. 4.3.5). Only about half of the added iron has been recovered by measuring iron concentration in the water column and exported iron in sediment traps (Table 8). The missing part in the mass balance indicates that either the concentrations in the water column or the sedimentation have been larger than measured. Therefore, we did not change model parameters to fit the data.

\subsubsection{Sensitivity study with respect to iron dissolution timescale}

A dissolution timescale of 3 days is used in our standard model setup, corresponding to the stage of fast dissolution in Wagener et al. (2008). Surface DFe drops rapidly in the first hours, adsorbing onto large particles in high abundance (Fig. 8). After that, it increases slightly and remains at $\sim 2 \mu \mathrm{mol} \mathrm{m}{ }^{-3}$ for about 2 days. This indicates a balance between iron dissolution and slower removal by small particles. The mixing event on early 14 June leads to a higher concentration of DFe in the surface water. Later on, DFe decreases linearly due to further removal by small particles, while no more iron is dissolved from dust particles. Atmospheric iron input has been often described in models under an implicit assumption of an instantaneous dissolution of iron from dust particles (e.g. Parekh et al., 2004; Aumont et al., 2008). To illustrate the effect of dissolution timescale on $\mathrm{Fe}$ input from dust deposition, we compared the standard run with a run with instantaneous dissolution. A huge increase of surface DFe up to $\sim 7.5 \mu \mathrm{mol} \mathrm{m}{ }^{-3}$ occurs in the first hours with instantaneous dissolution, which clearly disagrees 


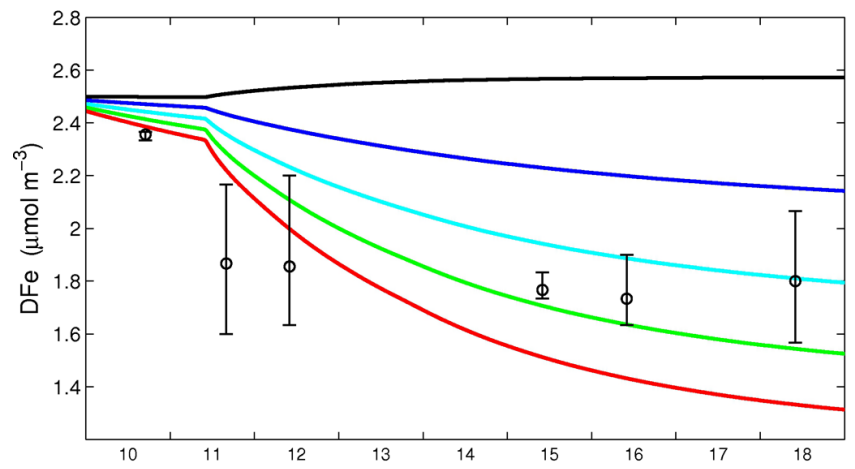

Fig. 9. Sensitivity study with respect to adsorption rate constant ( $\left.k_{\text {sorp }}\right)$. Depth-averaged DFe is plotted with $k_{\text {sorp }}=2.5$ (black), $2.5 \times 20$ (blue), $2.5 \times 40$ (light blue), $2.5 \times 60$ (green) and $2.5 \times$ 80 (red) $\mathrm{m}^{3} \mathrm{~kg}^{-1} \mathrm{~d}^{-1}$. Circles are measured DFe concentrations (depth-averaged). Error bars show the total range of measured data.

with the observation. This suggests that the role of dissolution timescale should be taken into account when studying the short-term impact of dust deposition on surface iron concentration.

\subsubsection{Sensitivity study with respect to adsorption rate}

Particle adsorption is described as a function of DFe concentration and total particle concentration. The measured rate constants for the adsorption of colloidal iron are hundreds of times higher than that of soluble ferric iron (Wen et al., 1997). In the sensitivity study with respect to the adsorption rate constant $k_{\text {sorp }}$, we started with the rate constant for direct scavenging of soluble ferric iron from Ye et al. (2009) $\left(2.5 \mathrm{~m}^{3} \mathrm{~kg}^{-1} \mathrm{~d}^{-1}\right)$ and then increased $k_{\text {sorp }} 20-, 40-, 60-$ and 80 -fold. The model run with the lowest $k_{\text {sorp }}$ shows a slight increase of DFe after the dust addition (Fig. 9), indicating that a much stronger scavenging is needed to reduce $\mathrm{DFe}$ concentration to the observed level by the given particle concentration. Comparing all the model runs, we found that higher adsorption rates lead to faster decrease of DFe after dust addition and lower DFe concentration at the end of the experiment. The observed DFe decrease of $\sim 1 \mu \mathrm{mol} \mathrm{m}^{-3}$ can be reproduced best by an enlargement of $k_{\text {sorp }}$ of 60 times over the adsorption of soluble iron from Ye et al. (2009).

The estimated adsorption rate constants in this sensitivity study $\left(30,150\right.$ and $750 \mathrm{~m}^{3} \mathrm{~kg}^{-1} \mathrm{~d}^{-1}$ for different particle classes) are higher than the estimate for adsorption of soluble iron by Nyffeler et al. (1984) $\left(25 \mathrm{~m}^{3} \mathrm{~kg}^{-1} \mathrm{~d}^{-1}\right)$ using sediment particles. Although different surface properties of particles can influence metal adsorption, we do not think that it can explain the high rate constant needed in our model. Compared to the rate of colloidal aggregation reported by Wen et al. (1997) $\left(1.2-51 \times 10^{-2} \mathrm{~h}^{-1}\right.$ with a particle concentration of $10 \mathrm{mg}^{-1}$ resulting in $240-1220 \mathrm{~m}^{3} \mathrm{~kg}^{-1} \mathrm{~d}^{-1}$ ), our estimates for the 2 smaller particle classes are lower and the
Table 7. Measured and modelled export flux of Fe $\left(\mathrm{mg} \mathrm{m}^{-2} \mathrm{~d}^{-1}\right)$ under dust addition. D1-D3 stand for the triplicate mesocosms with dust addition, $\mathrm{D}_{\text {ave }}$ for the mean of D1-D3 and M for model results. Numbers are averaged fluxes in the time periods after dust addition.

\begin{tabular}{lrrrr}
\hline & $24 \mathrm{~h}^{*}$ & $72 \mathrm{~h}$ & $120 \mathrm{~h}$ & $168 \mathrm{~h}$ \\
\hline D1 & 14.8 & 41.0 & 6.6 & 2.5 \\
D2 & 10.5 & 283 & 17.4 & 2.8 \\
D3 & 20.2 & 20.3 & 10.5 & 1.5 \\
D $_{\text {ave }}$ & 15.2 & 29.9 & 11.5 & 2.2 \\
M & 54.0 & 21.5 & 11.1 & 5.3 \\
\hline
\end{tabular}

* Exported mass from $24 \mathrm{~h}$ before to $24 \mathrm{~h}$ after the addition.

one for large aggregates is in the range of Wen's estimates. This indicates strongly that the model description of particle adsorption represents a combined effect of direct scavenging and colloidal aggregation and thus the rate estimate should be regarded as a gross constant of these two processes together. The significant role of colloidal iron in the Fe cycle is in agreement with recent findings that atmospheric iron mainly increases the colloidal pool of iron in seawater $(\mathrm{Wu}$ et al., 2001) and that the colloidal fraction accounts for a substantial portion of DFe throughout the water column (Cullen et al., 2006; Bergquist et al., 2007). This fraction of DFe should be considered explicitly in modelling iron removal, if direct observations of colloidal iron during dust fertilisation experiments are available.

\subsubsection{Iron budget}

The model reproduces the rapid decrease of DFe after the dust addition (Fig. 5b). DFe in surface water is elevated on 14 June because the lower water layer with higher DFe concentration becomes mixed with surface water. The pattern of $\mathrm{PFe}_{\text {sorp }}$ shows a different trend: it increases rapidly after the dust addition and remains relatively high until the end of the experiment (Fig. 10). Linked to the change of particle concentrations with time (Fig. 7), this results in a low iron loading per particle immediately after dust addition (down to $10^{-6} \mathrm{mg} \mathrm{Fe}$ per mg particle) and a high iron loading per particle at the end of the experiment (up to $10^{-3} \mathrm{mg}$ Fe per $\mathrm{mg}$ particle).

To compare with the iron budget estimated from measured data, we calculated total DFe and total particulate iron within the upper $15 \mathrm{~m}$ as well as the export of total particulate iron at $15 \mathrm{~m}$ from 0 to 24,120 and $168 \mathrm{~h}$ after the dust addition. Table 8 compares the measured distribution of Fe species in two mesocosms to the modelled one. Modelled DFe stock agrees well with the measurements, whereas PFe stock and export are both higher than the data (see also Table 7).

PFe stock is $2-5$ times higher in the model from $24 \mathrm{~h}$ after dust addition to the end of the experiment. Modelled $\mathrm{PFe}$ export is particularly high in the first $24 \mathrm{~h}$ after the dust 
Table 8. Iron budget estimated from measured data and model (mg) under dust addition. D1-D2 stand for the two mesocosms with dust addition shown in Wagener et al. (2010) and $\mathrm{M}$ for model results. Time (0-168) is in hours after dust addition. DFe and PFe stock are the total mass in the water column. PFe export is the cumulative export from dust addition to the corresponding time points. "recovery" is calculated as the sum of iron stock and export divided by the iron input by dust addition.

\begin{tabular}{llrrrrc}
\hline & & 0 & 24 & 120 & 168 & recovery (\%) \\
\hline D1 & DFe stock & 7 & 6 & 5 & 6 & \\
& PFe stock & 41 & 270 & 52 & 54 & 59 \\
& PFe export & 0 & 123 & 518 & 538 & \\
\hline D2 & DFe stock & 7 & 6 & 6 & 5 & \\
& PFe stock & 42 & 169 & 67 & 43 & 53 \\
& PFe export & 0 & 88 & 467 & 490 & \\
\hline M & DFe stock & 8 & 7 & 6 & 5 & \\
& PFe stock & 57 & 602 & 278 & 229 & 100 \\
& PFe export & 0 & 429 & 713 & 759 & \\
\hline
\end{tabular}

addition, whereas measured PFe is mainly exported between 24 and $120 \mathrm{~h}$ (Table 7). The same reasons for the discrepancy between model and data of inorganic particles should be responsible for that of PFe (see Sect. 4.3.2). The delayed high values in the measurement are also found in the export of particles (Table 6). This could be caused by the conical shape of mesocosm bottom which may have slowed up the sedimentation.

The sediment trap design and the uncertainties by sampling might explain why the recovery of added iron in the two mesocosms is only 59 and $53 \%$, respectively (Guieu et al., 2010). It would be helpful for further adjustment of our model to have measurements in a better spatial resolution and estimates of PFe loss through exchanging traps or adhering to mesocosms.

\section{Discussion}

\subsection{Role of dust deposition in iron replete waters}

The significant decrease of DFe induced by dust addition seems to contradict the often observed DFe increase after dust deposition (e.g. Vink and Measures, 2001; Bishop et al., 2002) and the general view of dust deposition as an important source of iron for open oceans (Duce and Tindale, 1991). How is it possible to interpret these in an integrative way?

Wagener et al. (2010) pointed out that the initial iron concentration before the dust addition was at the higher end of former measurements in that region. A Saharan dust deposition two weeks before the DUNE experiment and the rain events days before are supposed to be responsible for the high DFe initial concentration. Since particle surface adsorp-

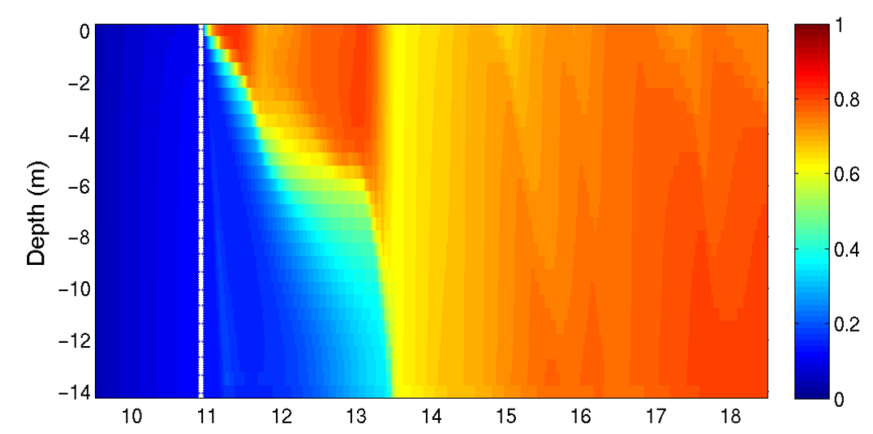

Fig. 10. Modelled PFe concentration $\left(\mu \mathrm{mol} \mathrm{m}{ }^{-3}\right)$ in DUST-meso. The white bar shows the time of dust addition.

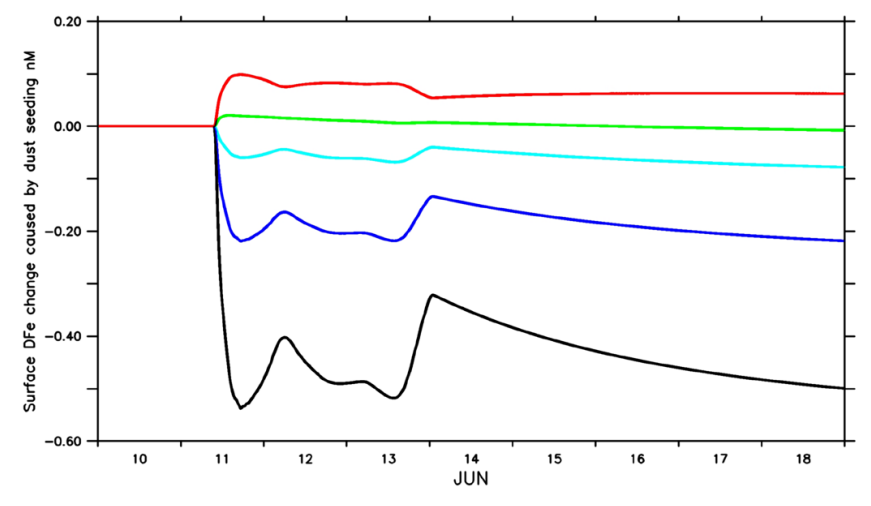

Fig. 11. Sensitivity study with respect to initial DFe concentration before dust addition. Surface DFe change caused by dust addition is calculated as the difference of surface DFe concentration with and without dust addition and plotted for different initial DFe concentrations: 2.0 (black), 1.0 (blue), 0.5 (light blue), 0.25 (green) and $0 \mu \mathrm{mol} \mathrm{m}{ }^{-3}$ (red).

tion not only depends on the amount of added particles but also on the ambient DFe in the medium before deposition, we hypothesise that the net impact of dust deposition on DFe ambient concentration depends in part on initial DFe concentration in seawater.

To test this hypothesis, several model runs were conducted with DFe initial concentrations varying from $0-2 \mu \mathrm{mol} \mathrm{m}{ }^{-3}$. The difference of surface DFe between a run with dust addition and a run without is illustrated in Fig. 11 for each initial $\mathrm{DFe}$ concentration, representing the net influence of dust addition on DFe concentration. A transition is found between 0.25 and $0.5 \mu \mathrm{mol} \mathrm{m}^{-3}$ : dust addition increases DFe concentration in seawater in the runs with initial DFe concentrations up to $0.25 \mu \mathrm{mol} \mathrm{m}{ }^{-3}$, whereas in the runs with higher initial DFe concentrations, dust addition lowers DFe concentration.

In the case of DUNE experiment, we assume that no excess ligands existed at the beginning of the experiment based on the batch dust dissolution experiments performed in parallel to the mesocosm experiments (Wagener et al., 2010). Biology played only a minor role in Fe cycling compared to 
physico-chemical processes: the modelled biological uptake increases up to $10^{-8} \mu \mathrm{mol} \mathrm{m}{ }^{-3} \mathrm{Fe} \mathrm{s}^{-1}$ after dust addition, whereas DFe is removed at a rate of $10^{-5} \mu \mathrm{mol} \mathrm{m}^{-3} \mathrm{Fe} \mathrm{s}^{-1}$ by particle adsorption, and sinking particles are evidently dominated by the inorganic fraction. Therefore, one may understand the effect of dust addition by only considering the balance between the abiotic $\mathrm{Fe}$ release and adsorption in the first moment after the addition.

The dissolution is given by Eq. (1):

$$
F_{\mathrm{diss}}=\frac{P_{\mathrm{dust}} r_{\mathrm{Fe}} r_{\mathrm{sol}} k_{\mathrm{rel}}}{M_{\mathrm{W}}}
$$

where $P_{\text {dust }}\left(\mathrm{kg} \mathrm{m}^{-3}\right)$ is the concentration of total dust particles, $r_{\mathrm{Fe}}(-)$ the Fe fraction in dust, $r_{\mathrm{sol}}(-)$ the Fe solubility, $k_{\text {rel }}\left(\mathrm{d}^{-1}\right)$ the rate of Fe release from dust particles (the reciprocal of the dissolution timescale), and $M_{\mathrm{W}}\left(\mathrm{g} \mathrm{mol}^{-1}\right)$ the molar weight of $\mathrm{Fe}$.

The adsorption is calculated by Eq. (2):

$F_{\text {sorp }}=P_{\text {dust }} k_{\text {sorp }} R_{\text {surf }} \mathrm{DFe} C$

where $k_{\text {sorp }}\left(\mathrm{m}^{3} \mathrm{~kg}^{-1} \mathrm{~d}^{-1}\right)$ is the mass-related adsorption rate of the middle-sized particles $\left(P_{\mathrm{S}}\right)$ and $R_{\text {surf }}(-)$ is the surface:volume ratio of the given particle size class relative to that of the middle size class. $C$ (nmol g mol${ }^{-1} \mathrm{~kg}^{-1}$ ) is a factor for unit conversion.

Assuming a balance between dissolution and adsorption (Eqs. 1-2), we define a critical concentration (DFe ${ }^{\text {crit }}$ ) that determines whether dust deposition acts as a source or a sink of DFe:

$\mathrm{DFe}^{\mathrm{crit}}=\frac{r_{\mathrm{Fe}} r_{\mathrm{sol}} k_{\mathrm{rel}}}{k_{\text {sorp }} R_{\text {surf }} M_{\mathrm{W}} C}$

where $\mathrm{DFe}^{\text {crit }}$ by definition has the dimension of a concentration and its size depends on the types of dust particles and on environmental conditions. This critical DFe concentration can be used to predict the impact of dust addition on DFe: if the initial DFe is greater than $\mathrm{DFe}^{\text {crit }}$, adsorption dominates and $\mathrm{DFe}$ will decrease towards $\mathrm{DFe}^{\text {crit }}$, whereas as DFe is lower than $\mathrm{DFe}^{\text {crit }}$, dissolution dominates and $\mathrm{DFe}$ will increase towards DFe ${ }^{\text {crit }}$. For the DUNE experiment, we calculated $R_{\text {surf }}$ from the surface:volume ratios and fractions of the two size classes of dust particles in the model and estimated a critical DFe concentration of $0.35 \mu \mathrm{mol} \mathrm{m}{ }^{-3}$.

In Eq. (3), we do not consider organic complexation of $\mathrm{Fe}$ which prevents DFe from scavenging removal. Therefore, this estimate represents a critical concentration of the reactive fraction of $\mathrm{DFe}-\mathrm{Fe}^{\prime}$, rather than of the total DFe. In a region with excess ligands, added iron should be kept longer in the dissolved pool even for higher initial DFe concentration. Since organic complexation is much faster than particle adsorption (Rose and Waite, 2003a), the critical DFe concentration with organic complexation present $\left(\mathrm{DFe}_{\text {lig }}^{\text {crit }}\right)$ can be calculated assuming an equilibrium between $\mathrm{Fe}^{\prime}$ and organic complexed iron (FeL). The conditional stability constant $K^{*}$ with respect to $\mathrm{Fe}^{\prime}$ is described by Eq. (4):

$K^{*}=\frac{\mathrm{FeL}}{L^{\prime} \mathrm{Fe}^{\prime}}$

$L^{\prime}$ is excess ligand and can be calculated from total ligand $\left(L_{\text {tot }}\right)$ :

$L^{\prime}=L_{\text {tot }}-\mathrm{FeL}$

With an additional equation of $\mathrm{DFe}_{\text {tot }}$ (Eq. 6), $\mathrm{DFe}_{\text {lig }}^{\text {crit }}$ is described as a function of $\mathrm{Fe}^{\prime}$ and $L_{\text {tot }}$ (Eq. 7) where $\mathrm{Fe}^{\prime}$ can be calculated as $\mathrm{DFe}^{\text {crit }}$ by Eq. (3):

$\mathrm{DFe}_{\mathrm{tot}}=\mathrm{Fe}^{\prime}+\mathrm{FeL}$

$$
\begin{aligned}
\mathrm{DFe}_{\text {lig }}^{\text {crit }} & =\mathrm{Fe}^{\prime}\left(1+\frac{K^{*} L_{\text {tot }}}{1+K^{*} \mathrm{Fe}^{\prime}}\right) \\
& =\mathrm{DFe}^{\text {crit }}\left(1+\frac{K^{*} L_{\text {tot }}}{1+K^{*} \mathrm{DFe}^{\text {crit }}}\right)
\end{aligned}
$$

This equation results in a higher critical DFe concentration in a system with excess ligands than without. The difference between these two depends on total ligands and $\mathrm{Fe}^{\prime}$ concentration. Assuming a ligand concentration of $3 \mu \mathrm{mol} \mathrm{m}{ }^{-3}$ measured at the JGOFS-DYFAMED time-series station in June 2006 (Wagener et al., 2008), combined with the same dust addition as in DUNE, a critical concentration of $\sim 3.4 \mu \mathrm{mol} \mathrm{m}{ }^{-3}$ results from Eq. (7), indicating that dust deposition could act as DFe source much longer in a system with high ligand abundance.

\subsection{Role of dust deposition in iron limiting waters}

The critical concentration of initial DFe in a system where $\mathrm{Fe}$ cycling is dominated by physico-chemical processes, is simply a solubility balance between dissolution and adsorption. In a system with strong Fe-limitation however, biological processes such as Fe uptake could influence the cycling of Fe considerably and the critical concentration is then a balance between total fluxes from and to dissolved Fe.

Iron could be the major limiting factor for phytoplankton growth in two types of ocean regions. The first is the HNLC regions where low DFe concentrations in surface waters are thought be to responsible for low chlorophyll concentrations (Martin, 1990). A strong dust event, corresponding to the dust addition during DUNE, would increase both DFe and phytoplankton growth there. Biological uptake however, should be still much smaller than Fe loss by particle adsorption, due to the low biomass before dust deposition. For instance, at the SOIREE site, the rate of biological Fe uptake was $\sim 0.6 \mathrm{nmol} \mathrm{m}^{-3} \mathrm{~d}^{-1}$ before the Fe fertilisation (Bowie et al, 2001). Assuming the same dust addition as in DUNE and an initial DFe concentration of $0.1 \mu \mathrm{mol} \mathrm{m}{ }^{-3}$, the adsorptive loss is over orders of magnitude higher than the uptake. Therefore, it is still a system dominated by physico-chemical 
processes and a critical concentration of $4.4 \mu \mathrm{mol} \mathrm{m}^{-3}$ is resulted from Eq. (7), using observed ligand concentration before the Fe fertilisation (Bowie et al, 2001). Comparing this to the measured DFe concentrations $\left(\ll 1 \mu \mathrm{mol} \mathrm{m}^{-3}\right)$ in the HNLC regions, dust deposition would act as a net source of DFe.

The second type of Fe limiting ocean regions contains some coastal regions where DFe is similarly high as at the DUNE site but phytoplankton growth may still be limited by iron, because other nutrients are more abundant. Due to the high biomass there, Fe cycling is strongly influenced by biological activities. Therefore, the impact of dust events on DFe in such a system can not be predicted by simply considering a solubility balance but by taking into account two additional fluxes from DFe: biological uptake and adsorption onto organic particles. The critical concentration of initial $\mathrm{DFe}$ is then estimated, based on the balance between dissolution, adsorption and biological uptake $F_{\text {upt }}\left(\mu \mathrm{mol} \mathrm{m}^{-3} \mathrm{~d}^{-1}\right)$ :

$F_{\text {diss }}=F_{\text {sorp } 2}+F_{\text {upt }}$

Organic particles are considered in particle adsorption $F_{\text {sorp2 }}$ $\left(\mu \mathrm{mol} \mathrm{m}{ }^{-3} \mathrm{~d}^{-1}\right)$ :

$F_{\text {sorp2 }}=\left(P_{\text {dust }}+P_{\text {init }}\right) k_{\text {sorp }} R_{\text {surf }} \mathrm{DFe} C$

where $P_{\text {init }}\left(\mathrm{kg} \mathrm{m}^{-3}\right)$ includes all the sinking particles (organic and inorganic) in seawater before dust deposition.

Combining Eqs. (1), (8) and (9), the critical DFe concentration considering all abiotic and biotic processes $\left(\mathrm{DFe}_{\text {full }}^{\text {crit }}\right.$, $\mu \mathrm{mol} \mathrm{m}^{-3}$ ) is derived:

$$
\begin{aligned}
& \mathrm{DFe}_{\text {full }}^{\text {crit }}= \\
& \frac{r_{\mathrm{Fe}} r_{\mathrm{sol}} k_{\mathrm{rel}}}{k_{\text {sorp }} R_{\text {surf }} M_{\mathrm{W}} C} \frac{P_{\text {dust }}}{P_{\text {dust }}+P_{\text {init }}}\left(1-\frac{F_{\text {upt }}}{P_{\text {dust }} r_{\mathrm{Fe}} r_{\mathrm{sol}} k_{\mathrm{rel}}}\right)
\end{aligned}
$$

where the first part is again the critical concentration for an abiotic system $\mathrm{DFe}^{\text {crit }}$ (Eq. 3). Generally, high uptake rate and high concentration of organic particles lower the critical concentration and accelerate the DFe decrease after dust deposition, if the initial DFe concentration exceeds the critical one.

This concept of the critical concentration of initial DFe is a tool to predict the net impact of dust deposition on seawater DFe concentration in different ocean systems: in the oligotrophic and HNLC regions with (Eq. 7) and without excess organic ligands (Eq. 3), as well as in the Fe-limiting coastal regions (Eq. 10). To assess the general applicability of this concept, more local observations of DFe change after dust deposition are needed and the role of excess ligands must be more carefully examined. Because of the complex feedback mechanisms of an ecosystem to dust deposition (Wagener et al., 2010), this concept might be only applicable for explaining the short-term change of DFe and immediate biological responses to dust events. However, it clearly points out that natural dust deposition could have different effects on DFe surface concentration due to different initial conditions. This might help in understanding the discrepancies between observed biological responses to natural dust deposition (Boyd et al., 2010) and predicting the bioavailability of iron in different ocean regions in a world with changing dust deposition.

\section{Conclusions}

A significant decrease of dissolved iron concentration has been observed after dust addition in a LNLC system in which $\mathrm{Fe}$ cycling is dominated by physico-chemical rather than biological processes. To simulate the experiment and study the mechanisms controlling DFe change, processes such as dissolution, scavenging, biological uptake, photoreduction and redissolution of particulate iron are described in a onedimensional model of the Fe cycle coupled with a simple NPZD-type ecosystem model based on phosphorus. Different size classes of sinking particles and particle aggregation have been taken into account.

A good agreement of modelled and measured particle sedimentation is found under control condition. This provides evidence that the model description and parameter choice of particle aggregation and sinking are applicable for explaining particle dynamics during the DUNE experiment. In the mesocosms with dust addition, about $50 \%$ of the added iron was recovered in the measurements which might be caused by loss during exchange of sediment traps and/or by adhering to the conical part of mesocosms. Modelled concentration and export of particles and particulate iron are significantly higher than measured, leading to a closed mass balance.

The DFe decrease is well reproduced with a dissolution timescale of 3 days and high adsorption rate constants of 30 , 150 and $750 \mathrm{~m}^{3} \mathrm{~kg}^{-1} \mathrm{~d}^{-1}$ for different particle size classes. The required longer dissolution timescale, in contrast to an instantaneous dissolution, indicates the importance of taking into account the dissolution timescale in studies on the short-term impact of dust deposition on surface iron concentrations. The model-estimated adsorption rate constants are generally higher than measured adsorption rate constants for soluble iron and lower than those for colloidal iron. This suggests that the removal pathway of dissolved iron via colloidal aggregation should be considered besides the direct scavenging of soluble iron to explain the rapid decrease of DFe. Direct measurements on colloidal iron during future dust addition experiments would help to improve our understanding of iron loss kinetics.

Dust deposition acts as a source and a sink of DFe at the same time. The initial DFe concentration before dust deposition has been shown to be crucial for determining whether dust deposition is a net source or sink of dissolved iron. A critical DFe concentration, above which dust deposition acts as a net sink of iron, rather than a source, can be estimated from the balance between fluxes from and to dissolved iron. 
In an abiotic system, this could be interpreted as a balance between iron release from and iron loss to particles; whereas in a biology-dominating system, biological uptake and adsorption onto organic particles accelerate the iron loss and lower the critical concentration. This concept of a critical DFe concentration could be used to predict the immediate impact of dust deposition on seawater DFe in different ocean regions, depending on characteristics of dust particles (e.g. iron solubility, surface:volume ratio), of seawater (e.g. iron binding ligand concentration) and of biology (e.g. growth limitation, biomass, properties of organic particles).

\section{Appendix A}

\section{Model equations}

The rate of change of biogeochemical variables is described by a biogeochemical and a physical part:

$\frac{\partial}{\partial t} X=\mathrm{BIO}+M(X, z)$

Advection and mixing are taken into account in the physical part $M(X, z)$. $M$ stands for the advection and mixing operator and $X$ is the mixed compound. The change rate of the biogeochemical part is described by corresponding sources minus sinks. Parameters used in model equations are listed in Tables 3 and 1.

\section{A1 Equations for the biological model}

The change of the biological variables DIP, PHY, ZOO, $\mathrm{D}_{\mathrm{s}}$ and $\mathrm{D}_{1}\left(\right.$ in $\mathrm{mmol} \mathrm{m}^{-3}$ ) is described by:

$$
\begin{aligned}
\frac{\partial}{\partial t} \mathrm{DIP} & =\gamma_{\mathrm{d}} f_{T}\left(\mathrm{D}_{\mathrm{s}}+\mathrm{D}_{1}\right)+\gamma_{\mathrm{zb}} f_{T} \mathrm{ZOO} \\
& +\gamma_{\mathrm{p}} f_{T} \mathrm{PHY}-\mu \mathrm{PHY}+M(\mathrm{DIP}, z) \\
\frac{\partial}{\partial t} \mathrm{PHY} & =\left(\mu-\gamma_{\mathrm{p}} f_{T}\right) \mathrm{PHY}-f_{\mathrm{G}} \mathrm{ZOO} \\
& -\gamma_{\mathrm{p}^{2}} \mathrm{PHY}^{2}+M(\mathrm{PHY}, z)
\end{aligned}
$$

$\mu$ is the growth rate of phytoplankton regarding light, temperature and nutrient limitation. The light limited growth rate is described by:

$$
f_{\mathrm{I}}=\frac{\mu_{\max } \alpha I(z)}{\left(\mu_{\max }^{2}+(\alpha I(z))^{2}\right)^{0.5}}
$$

where $I(z)$ is the photosynthetically active radiation in the given water layer $z$. Both growth and remineralisation rate are related to temperature by:

$f_{T}=0.9 C_{\mathrm{ref}^{T}}^{T}$

which represents a temperature dependence for $Q_{10}=2$. The growth limitation by iron depends on the internal Fe:P-quota
$Q_{\mathrm{Fe}}$ according to:

$f_{\mathrm{Fe}}=\frac{Q_{\mathrm{Fe}}-Q_{\mathrm{Fe}}^{\min }}{Q_{\mathrm{Fe}}}$

where $Q_{\mathrm{Fe}}^{\min }$ is a minimal cellular Fe quota. The actual growth rate is then the product of the light and temperature dependent maximal growth rate with the smaller of $f_{\mathrm{Fe}}$ and $f_{\mathrm{P}}$, a Michaelis-Menten term in dissolved inorganic phosphorus:

$f_{\mathrm{P}}=\frac{\mathrm{DIP}}{\mathrm{DIP}+K_{\mathrm{P}}}$

where $K_{\mathrm{P}}$ is a half-saturation constant for DIP uptake.

$\mathrm{ZOO}$ change rate is determined by the rate of grazing, excretion and mortality.

$$
\begin{aligned}
\frac{\partial}{\partial t} \mathrm{ZOO} & =\gamma_{\mathrm{za}} f_{\mathrm{G}} \mathrm{ZOO}-\gamma_{\mathrm{zb}} f_{T} \mathrm{ZOO} \\
& -\gamma_{\mathrm{z}^{2}} \mathrm{ZOO}^{2}+M(\mathrm{ZOO}, z)
\end{aligned}
$$

The grazing function $f_{\mathrm{G}}$ depends on the maximal grazing rate $g$, the prey capture rate $\epsilon$ and phytoplankton concentration:

$f_{\mathrm{G}}=\frac{g \epsilon \mathrm{PHY}^{2}}{g+\epsilon \mathrm{PHY}^{2}}$

The loss of zooplankton by its mortality $\left(\gamma_{\mathrm{Z}^{2}} \mathrm{ZOO}^{2}\right)$ is considered as a source of organic aggregates.

Detritus is divided into two size classes: $D_{\mathrm{s}}$ for small and $\mathrm{D}_{1}$ for large detritus. We use the same symbols for organic part of small aggregates and large aggregates, respectively, because we treat them same as the detritus in particle aggregation, sinking and remineralisation.

$$
\begin{aligned}
\frac{\partial}{\partial t} \mathrm{D}_{\mathrm{s}} & =\gamma_{\mathrm{p}^{2}} \mathrm{PHY}^{2}+\left(1-\gamma_{\mathrm{za}}\right) f_{\mathrm{G}} \mathrm{ZOO}-\gamma_{\mathrm{d}} f_{T} \mathrm{D}_{\mathrm{s}} \\
& -k_{\mathrm{coag} 2} \mathrm{D}_{\mathrm{s}}\left(\mathrm{D}_{\mathrm{s}} r_{\mathrm{m}: \mathrm{P}}+P_{\mathrm{s}}\right)-k_{\mathrm{coag} 3} \mathrm{D}_{\mathrm{s}}\left(\mathrm{D}_{1} r_{\mathrm{m}: \mathrm{P}}+P_{1}\right) \\
& -w_{\mathrm{s}} \frac{\partial \mathrm{D}_{\mathrm{s}}}{\partial z}+M\left(\mathrm{D}_{\mathrm{s}}, z\right) \\
\frac{\partial}{\partial t} \mathrm{D}_{1} & =\gamma_{\mathrm{z}^{2}} \mathrm{ZOO}^{2}-\gamma_{\mathrm{d}} f_{T} \mathrm{D}_{1}+k_{\mathrm{coag} 2} \mathrm{D}_{\mathrm{s}}\left(\mathrm{D}_{\mathrm{s}} r_{\mathrm{m}: \mathrm{P}}+P_{\mathrm{s}}\right) \\
+ & k_{\mathrm{coag} 3} \mathrm{D}_{\mathrm{s}}\left(\mathrm{D}_{1} r_{\mathrm{m}: \mathrm{P}}+P_{1}\right)-w_{1} \frac{\partial \mathrm{D}_{1}}{\partial z}+M\left(\mathrm{D}_{1}, z\right)
\end{aligned}
$$

\section{A2 Equations for inorganic sinking particles}

Inorganic sinking particles are fine dust particles $P_{\mathrm{d}}$, coarse dust particles and the inorganic fraction of small aggregates $P_{\mathrm{S}}$ and the inorganic fraction of large aggregates $P_{1}$ (all in $\mathrm{kg} \mathrm{m}^{-3}$ ). Coagulation is described by a coagulation constant $k_{\text {coag }}$ times the product of concentration of the two particle classes involved in the coagulation.

$$
\begin{aligned}
& \frac{\partial}{\partial t} P_{\mathrm{d}}=F_{\text {surf }}^{\mathrm{d}}-k_{\text {coag } 1} P_{\mathrm{d}}\left(\mathrm{D}_{\mathrm{s}} r_{\mathrm{m}: \mathrm{P}}+P_{\mathrm{s}}\right) \\
& -k_{\text {coag } 4} P_{\mathrm{d}}\left(\mathrm{D}_{1} r_{\mathrm{m}: \mathrm{P}}+P_{1}\right)-w_{\mathrm{d}} \frac{\partial P_{\mathrm{d}}}{\partial z}+M\left(P_{\mathrm{d}}, z\right)
\end{aligned}
$$




$$
\begin{aligned}
\frac{\partial}{\partial t} P_{\mathrm{s}} & =F_{\mathrm{surf}}^{\mathrm{s}}+k_{\mathrm{coag} 1} P_{\mathrm{d}}\left(\mathrm{D}_{\mathrm{s}} r_{\mathrm{m}: \mathrm{P}}+P_{\mathrm{s}}\right)-k_{\mathrm{coag} 3} P_{s} \\
& \left(\mathrm{D}_{1} r_{\mathrm{m}: \mathrm{P}}+P_{\mathrm{l}}\right)-k_{\mathrm{coag} 2} P_{\mathrm{s}}\left(\mathrm{D}_{\mathrm{s}} r_{\mathrm{m}: \mathrm{P}}+P_{\mathrm{s}}\right) \\
& -w_{\mathrm{s}} \frac{\partial P_{\mathrm{s}}}{\partial z}+M\left(P_{\mathrm{s}}, z\right) \\
\frac{\partial}{\partial t} P_{\mathrm{l}} & =k_{\mathrm{coag} 4} P_{\mathrm{d}}\left(\mathrm{D}_{1} r_{\mathrm{m}: \mathrm{P}}+P_{\mathrm{l}}\right)+k_{\mathrm{coag} 3} P_{\mathrm{s}}\left(\mathrm{D}_{1} r_{\mathrm{m}: \mathrm{P}}+P_{1}\right) \\
& +k_{\mathrm{coag} 2} P_{\mathrm{s}}\left(\mathrm{D}_{\mathrm{s}} r_{\mathrm{m}: \mathrm{P}}+P_{\mathrm{s}}\right)-w_{1} \frac{\partial P_{1}}{\partial z}+M\left(P_{1}, z\right)
\end{aligned}
$$

$F_{\text {surf }}^{\mathrm{d}}$ and $F_{\text {surf }}^{\mathrm{s}}$ are the surface fluxes of dust particles where $33 \%$ of the total flux is put into $P_{\mathrm{d}}$ and $67 \%$ into $P_{\mathrm{s}} . r_{\mathrm{m}: \mathrm{P}}$ is a factor converting biomass from $\mathrm{mmol} \mathrm{P} \mathrm{m}^{-3}$ into $\mathrm{kg} \mathrm{m}^{-3}$.

\section{A3 Equations for the iron cycle}

DFe change is described by:

$$
\begin{aligned}
\frac{\partial}{\partial t} \mathrm{DFe} & =k_{\mathrm{rel}}\left(\mathrm{Fe}_{\mathrm{dust}}^{\mathrm{d}}+\mathrm{Fe}_{\mathrm{dust}}^{\mathrm{s}}\right)+\gamma_{\mathrm{d}} f_{T}\left(\mathrm{DS}_{\mathrm{Fe}}+\mathrm{DL}_{\mathrm{Fe}}\right) \\
& +\gamma_{\mathrm{p}} f_{T} \mathrm{PHY}_{\mathrm{Fe}}+\gamma_{\mathrm{zb}} f_{T} \mathrm{ZOO}_{\mathrm{Fe}}+\left(f_{\mathrm{I}}^{\mathrm{ph}} k_{\mathrm{ph}}+k_{\mathrm{pd}}\right) \\
& \left(\mathrm{PFe}_{\mathrm{d}}+\mathrm{PFe}_{\mathrm{s}}+\mathrm{PFe}_{1}\right)-k_{\mathrm{upt}}-k_{\mathrm{sorp}}\left(P_{\mathrm{d}} R_{\text {surf }}^{\mathrm{d}}\right. \\
& \left.+\left(P_{\mathrm{s}}+\mathrm{D}_{\mathrm{s}} r_{\mathrm{m}: \mathrm{P}}\right) R_{\mathrm{surf}}^{\mathrm{s}}+\left(P_{1}+\mathrm{D}_{1} r_{\mathrm{m}: \mathrm{P}}\right) R_{\mathrm{surf}}^{1}\right) \mathrm{DFe} \\
& +M(\mathrm{DFe}, z)
\end{aligned}
$$

where $\mathrm{Fe}_{\text {dust }}^{\mathrm{d}}$ and $\mathrm{Fe}_{\text {dust }}^{\mathrm{s}}$ are the two dissolvable pools of iron in dust particles. Iron release from these pools is dependent on the dissolution rate $k_{\text {rel }}$. A function of light intensity $f_{\mathrm{I}}^{\mathrm{ph}}$ is introduced in the photochemical reduction of PFe:

$f_{\mathrm{I}}^{\mathrm{ph}}=\frac{I(z)}{I_{\mathrm{ref}}}$

The DFe uptake $k_{\text {upt }}$ by phytoplankton is determined by:

$k_{\text {upt }}=\min \left(\mu_{\max } \frac{\mathrm{DFe}}{\left(\mathrm{DFe}+K_{\mathrm{Fe}}\right)} \mathrm{PHY}, \mu Q_{\mathrm{Fe}}^{\mathrm{ave}} \mathrm{PHY}\right)$

$Q_{\mathrm{Fe}}^{\mathrm{ave}}$ is the mean Fe:P ratio of phytoplankton. Choosing the smaller one of the terms ensures a dependence of uptake on DFe availability and a storage uptake is not considered.

$\mathrm{PFe}$ is divided in three classes due to the adsorption on different particles: $\mathrm{PFe}_{\mathrm{d}}$ adsorbs on $P_{\mathrm{d}}, \mathrm{PFe}_{\mathrm{s}}$ on $P_{\mathrm{s}}$ and $\mathrm{D}_{\mathrm{s}}$, $\mathrm{PFe}_{1}$ on $P_{1}$ and $\mathrm{D}_{1}$.

$$
\begin{aligned}
& \frac{\partial}{\partial t} \mathrm{PFe}_{\mathrm{d}}=k_{\mathrm{sorp}} R_{\text {surf }}^{\mathrm{d}} \mathrm{DFe} P_{\mathrm{d}}-\left(f_{\mathrm{I}}^{\mathrm{ph}} k_{\mathrm{ph}}+k_{\mathrm{pd}}\right) \mathrm{PFe}_{\mathrm{d}} \\
& \quad-k_{\mathrm{coag} 1} \mathrm{PFe}_{\mathrm{d}}\left(\mathrm{D}_{\mathrm{s}} r_{\mathrm{m}: \mathrm{P}}+P_{\mathrm{s}}\right)-k_{\mathrm{coag} 4} \mathrm{PFe}_{\mathrm{d}}\left(\mathrm{D}_{1} r_{\mathrm{m}: \mathrm{P}}+P_{1}\right) \\
& \quad-w_{\mathrm{d}} \frac{\partial \mathrm{PFe}_{\mathrm{d}}}{\partial z}+M\left(\mathrm{PFe}_{\mathrm{d}}, z\right) \\
& \frac{\partial}{\partial t} \mathrm{PFe}_{\mathrm{s}}=k_{\mathrm{sorp}} R_{\mathrm{surf}}^{\mathrm{s}} \mathrm{DFe}\left(r_{\mathrm{m}: \mathrm{P}} \mathrm{D}_{\mathrm{s}}+P_{\mathrm{s}}\right) \\
& \quad+k_{\mathrm{coag} 1} \mathrm{PFe}_{\mathrm{d}}\left(\mathrm{D}_{\mathrm{s}} r_{\mathrm{m}: \mathrm{P}}+P_{\mathrm{s}}\right)-k_{\mathrm{coag} 3} \mathrm{PFe}_{\mathrm{s}}\left(\mathrm{D}_{1} r_{\mathrm{m}: \mathrm{P}}+P_{1}\right) \\
& \quad-k_{\mathrm{coag} 2} \mathrm{PFe}_{\mathrm{s}}\left(\mathrm{D}_{\mathrm{s}} r_{\mathrm{m}: \mathrm{P}}+P_{\mathrm{s}}\right)-\left(f_{\mathrm{I}}^{\mathrm{ph}} k_{\mathrm{ph}}+k_{\mathrm{pd}}\right) \mathrm{PFe}_{\mathrm{s}} \\
& \quad-w_{\mathrm{s}} \frac{\partial \mathrm{PFe}}{\partial z}+M\left(\mathrm{PFe}_{\mathrm{s}}, z\right)
\end{aligned}
$$

$$
\begin{aligned}
\frac{\partial}{\partial t} & \mathrm{PFe}_{1}=k_{\mathrm{sorp}} R_{\text {surf }}^{1} \mathrm{DFe}\left(r_{\mathrm{m}: \mathrm{P}} \mathrm{D}_{1}+P_{1}\right)+k_{\mathrm{coag} 4} \mathrm{PFe}_{\mathrm{d}} \\
& \left(\mathrm{D}_{1} r_{\mathrm{m}: \mathrm{P}}+P_{1}\right)+k_{\mathrm{coag} 2} \mathrm{PFe}_{\mathrm{s}}\left(\mathrm{D}_{\mathrm{s}} r_{\mathrm{m}: \mathrm{P}}+P_{\mathrm{s}}\right)+k_{\mathrm{coag} 3} \mathrm{PFe}_{\mathrm{s}}, \\
& \left(\mathrm{D}_{1} r_{\mathrm{m}: \mathrm{P}}+P_{1}\right)-\left(f_{\mathrm{I}}^{\mathrm{ph}} k_{\mathrm{ph}}+k_{\mathrm{pd}}\right) \mathrm{PFe}_{1} \\
& -w_{1} \frac{\partial \mathrm{PFe}_{1}}{\partial z}+M\left(\mathrm{PFe}_{1}, z\right)
\end{aligned}
$$

Finally, a variable Fe:P-quota is introduced in PHY, ZOO, and DET and evolution of the respective Fe concentrations $\mathrm{PHY}_{\mathrm{Fe}}, \mathrm{ZOO}_{\mathrm{Fe}}, \mathrm{DS}_{\mathrm{Fe}}$ (for iron contained in small detritus) and $\mathrm{DL}_{\mathrm{Fe}}$ (for iron contained in large detritus) is described by:

$$
\begin{aligned}
\frac{\partial}{\partial t} \mathrm{PHY}_{\mathrm{Fe}} & =k_{\mathrm{upt}}-Q_{\mathrm{Fe}}\left(f_{\mathrm{G}} \mathrm{ZOO}+\gamma_{\mathrm{p}^{2}} \mathrm{PHY}^{2}\right) \\
& -\gamma_{\mathrm{p}} f_{T} \mathrm{PHY}_{\mathrm{Fe}}+M(\mathrm{PHY}, z)
\end{aligned}
$$

$$
\begin{aligned}
\frac{\partial}{\partial t} \mathrm{ZOO}_{\mathrm{Fe}} & =Q_{\mathrm{Fe}} \gamma_{\mathrm{za}} f_{\mathrm{G}} \mathrm{ZOO}-\gamma_{\mathrm{zb}} f_{T} \mathrm{ZOO}_{\mathrm{Fe}} \\
& -Q_{\mathrm{ZFe}} \gamma_{\mathrm{z}^{2}} \mathrm{ZOO}^{2}+M\left(\mathrm{ZOO}_{\mathrm{Fe}}, z\right)
\end{aligned}
$$

$$
\begin{aligned}
& \frac{\partial}{\partial t} \mathrm{DS}_{\mathrm{Fe}}=Q_{\mathrm{Fe}} \gamma_{\mathrm{p}^{2}} \mathrm{PHY}^{2}+Q_{\mathrm{Fe}}\left(1-\gamma_{\mathrm{za}}\right) f_{\mathrm{G}} \mathrm{ZOO} \\
& \quad-k_{\mathrm{coag} 2} \mathrm{DS}_{\mathrm{Fe}}\left(\mathrm{D}_{\mathrm{s}} r_{\mathrm{m}: \mathrm{P}}+P_{\mathrm{s}}\right)-k_{\mathrm{coag} 3} \mathrm{DS}_{\mathrm{Fe}}\left(\mathrm{D}_{1} r_{\mathrm{m}: \mathrm{P}}+P_{1}\right) \\
& \quad-\gamma_{\mathrm{d}} f_{T} \mathrm{DS}_{\mathrm{Fe}}+M\left(\mathrm{DS}_{\mathrm{Fe}}, z\right)
\end{aligned}
$$

$$
\begin{aligned}
& \frac{\partial}{\partial t} \mathrm{DL}_{\mathrm{Fe}}=Q_{\mathrm{ZFe}} \gamma_{\mathrm{Z}^{2}} \mathrm{ZOO}^{2}+k_{\mathrm{coag} 2} \mathrm{DS}_{\mathrm{Fe}}\left(\mathrm{D}_{\mathrm{s}} r_{\mathrm{m}: \mathrm{P}}+P_{\mathrm{s}}\right) \\
& \quad+k_{\mathrm{coag} 3} \mathrm{DS}_{\mathrm{Fe}}\left(\mathrm{D}_{1} r_{\mathrm{m}: \mathrm{P}}+P_{1}\right)-\gamma_{\mathrm{d}} f_{T} \mathrm{DL}_{\mathrm{Fe}} \\
& \quad+M\left(\mathrm{DL}_{\mathrm{Fe}}, z\right)
\end{aligned}
$$

where $Q_{Z F e}$ is the internal Fe:P ratio in zooplankton.

Acknowledgements. We thank Alessandro Tagliabue and the anonymous reviewer for helpful comments on the manuscript. This work is a contribution to the project SOPRAN (Surface Ocean Processes in the ANtropocene), which is funded by the German Federal Ministry of Education and Research (BMBF project $03 \mathrm{~F} 0462 \mathrm{C}$ ). The mesocosm experimental study was funded by the ANR DUNE under the contract ANR-07-BLAN-0126-01. The work of T. Wagener was supported by a Marie Curie IEF, Grant agreement No.: PIEF-GA-2009-236694, DAPOP. We would like to thank the "Réserve naturelle de Scandola, Parc naturel régional de Corse", in particular J. M. Dominici and collaborators, for professionalism and cooperation in the implementation of the field work in the Elbo bay. F. Louis, J. M. Grisoni, D. Luquet, M. Deschatres, C. Ridame, E. Pulido-Villena, S. Blain, C. Brunet, L. Gilleta and C. Rouvières are greatly acknowledged for their involvement during the DUNE-1 experiment. Sincerely, we thank the Japan Meteorological Agency Climate Data Assimilation System (JCDAS) for the free access of data.

Edited by: F. Chai 


\section{References}

Armstrong, R., Lee, C., Hedges, J., Honjo, S., and Wakeham, S.: A new, mechanistic model for organic carbon fluxes in the ocean based on the quantitative association of POC with ballast minerals, Deep-Sea Res. Pt. II, 49, 219-236, 2002.

Aumont, O., Bopp, L., and Schulz, M.: What does temporal variability in aeolian dust deposition contribute to sea-surface iron and chlorophyll distributions?, Geophys. Res. Lett., 35, L07607, doi:10.1029/2007GL031131, 2008.

Baker, A. and Croot, P.: Atmospheric and marine controls on aerosol iron solubility in seawater, Marine Chemistry, 120, 4-13, doi:10.1016/j.marchem.2008.09.003, 2010.

Baker, A., Kelly, S., Biswas, K., Witt, M., and Jickells, T.: Atmospheric deposition of nutrients to the Atlantic Ocean, Geophys. Res. Lett., 30, 30(24), 2296, doi:10.1029/2003GL018518, 2003.

Balistieri, L., Brewer, P., and Murray, J.: Scavenging residence times of trace metals and surface chemistry of sinking particles in the deep ocean, Deep-Sea Res., 28A, 101-121, 1981.

Bergquist, B., Wu, J., and Boyle, E.: Variability in oceanic dissolved iron is dominated by the colloidal fraction, Geochim. Cosmochim. Ac., 71, 2960-2974, doi:10.1016/j.gca.2007.03.013, 2007.

Bishop, J. K. B., Davis, R. E., and Sherman, J. T.: Robotic Observations of Dust Storm Enhancement of Carbon Biomass in the North Pacific, Science, 298, 817-821, 2002.

Bonnet, S. and Guieu, C.: Dissolution of atmospheric iron in seawater, Geophys. Res. Lett., 31, 1-4, 2004.

Bowie, A. R., Maldonado, M. T., Frew, R. D., Croot, P. L., Achterberg, E. P., Mantoura, R. F. C., Worsfold, P. J., Law, C. S. and Boyd, P. W.: The fate of added iron during a mesoscale fertilisation experiment in the Southern Ocean, Deep-Sea Res. Pt. II, 48, 2703-2743, 2001.

Boyd, P., Mackie, D., and Hunter, K.: Aerosol iron deposition to the surface ocean - Modes of iron supply and biological responses, Mar. Chem., 120, 128-143, doi:10.1016/j.marchem.2009.01.008, 2010.

Boyd, P. W., McTainsh, G., Sherlock, V., Richardson, K., Nichol, S., Ellwood, M., and Frew, R.: Episodic enhancement of phytoplankton stocks in New Zealand subantarctic waters: Contribution of atmospheric and oceanic iron supply, Global Biogeochem. Cy., 18, 1-23, 2004.

Boyd, P. W., Jickells, T., Law, C. S., Blain, S., Boyle, E. A., Buesseler, K. O., Coale, K. H., Cullen, J. J., de Baar, H. J. W., Follows, M., Harvey, M., Lancelot, C., Levasseur, M., Owens, N. P. J., Pollard, R., Rivkin, R. B., Sarmiento, J., Schoemann, V., Smetacek, V., Takeda, S., Tsuda, A., Turner, S., and Watson, A. J.: Mesoscale Iron Enrichment Experiments 1993-2005: Synthesis and Future Directions, Science, 315, 612-617, 2007.

Bruland, K. W. and Rue, E. L.: Analytical methods for the determination of concentrations and speciation of iron, in: The Biogeochemistry of Iron in Seawater, edited by: Turner, D. and Hunter, K., SCOR/IUPAC Series, J. Wiley, 1-7, 2001.

Burchard, H. and Umlauf, L.: Observations and numerical modelling of mixed-layer turbulence: Do they represent the same statistical quantities?, Deep-Sea Res. Pt. II, 52, 1069-1074, doi:10.1016/j.dsr2.2005.03.002, 2005.

Cullen, J., Bergquist, B., and Moffett, J.: Thermodynamic characterization of the partitioning of iron between soluble and colloidal species in the Atlantic Ocean, Mar. Chem., 98, 295-303,
2006.

de Baar, H., Boyd, P., Coale, K., Landry, M., Tsuda, A., Assmy, P., Bakker, D., Bozec, Y., Barber, R., Brzezinski, M., Buesseler, K., Boye, M., Croot, P., Gervais, F., Gorbunov, M., Harrison, P., Hiscock, W., Laan, P., Lancelot, C., Law, C., Levasseur, M., Marchetti, A., Millero, F., Nishioka, J., Nojiri, Y., van Oijen, T., Riebesell, U., Rijkenberg, M., Saito, H., Takeda, S., Timmermans, K., Veldhuis, M., Waite, A., and Wong, C.-S.: Synthesis of iron fertilization experiments: From the iron age in the age of enlightenment, J. Geophys. Res.-Oceans, 110, 1-24, 2005.

Duce, R. and Tindale, N.: Atmospheric transport of iron and its deposition in the ocean, Limnol. Oceanogr., 36, 1715-1726, 1991.

Guieu, C.: DUNE - a DUst experiment in a low Nutrient, low chlorophyll Ecosystem - Quantifying the role of atmospheric input on marine ecosystem using large clean mesocosms, SOLAS Newsl., 9, 36-37, 2009.

Guieu, C., Dulac, F., Desboeufs, K., Wagener, T., Pulido-Villena, E., Grisoni, J.-M., Louis, F., Ridame, C., Blain, S., Brunet, C., Bon Nguyen, E., Tran, S., Labiadh, M., and Dominici, J.M.: Large clean mesocosms and simulated dust deposition: a new methodology to investigate responses of marine oligotrophic ecosystems to atmospheric inputs, Biogeosciences, 7, 27652784, doi:10.5194/bg-7-2765-2010, 2010.

Guieu, C., Ridame, C., Pulido-Villena, E., Blain, S., Wagener, T., Dulac, F., Desboeufs, K., Pondaven, P., Leblond, N., Stemman, L., Obernesterer, I., and Dominici, J-M: Atmospheric deposition onto oligotrophic marine systems: new insights from mesocosm studies, in preparation, 2011.

Herut, B., Zohary, T., Krom, M., Mantoura, R., Pitta, P., Psarra, S., Rassoulzadegan, F., Tanaka, T., and Thingstad, T.: Response of East Mediterranean surface water to Saharan dust: On-board microcosm experiment and field observations, Deep-Sea Res. Pt. II, 52, 3024-3040, doi:10.1016/j.dsr2.2005.09.003, 2005.

Honeyman, B. and Santschi, P.: A Brownian-pumping model for trace metal scavenging: evidence from Th isotopes, J. Mar. Res., 47, 951-992, 1989.

Honeyman, B. D., Balistrieri, L. S., and Murray, J. W.: Oceanic trace metal scavenging: the importance of particle concentration, Deep-Sea Res., 35, 227-246, doi:10.1016/0198-0149(88)900386, 1988.

Honjo, S., Manganini, S., and Poppe, L.: Sedimentation of lithogenic particles in the deep ocean., Mar. Geol., 50, 199-220, 1982.

Hutchins, D. and Bruland, K.: Iron-limited diatom growth and Si:N uptake ratios in a coastal upwelling regime, Nature, 393, 561564, 1998.

Jickells, T. D., An, Z. S., Andersen, K. K., Baker, A. R., Bergametti, G., Brooks, N., Cao, J. J., Boyd, P. W., Duce, R. A., Hunter, K. A., Kawahata, H., Kubilay, N., laRoche, J., Liss, P. S., Mahowald, N., Prospero, J. M., Ridgwell, A. J., Tegen, I., and Torres, R.: Global Iron Connections Between Desert Dust, Ocean Biogeochemistry, and Climate, Science, 308, 67-71, 2005.

Johnson, K., Coale, K., Elrod, V., and Tindale, N.: Iron photochemistry in seawater from the equatorial Pacific, Mar. Chem., 46, 319-334, 1994.

Johnson, K. S., Elrod, V. A., Fitzwater, S. E., Plant, J. N., Chavez, F. P., Tanner, S. J., Gordon, R. M., Westphal, D. L., Perry, K. D., Wu, J., and Karl, D. M.: Surface ocean-lower atmosphere interactions in the Northeast Pacific Ocean Gyre: Aerosols, iron, and 
the ecosystem response, Global Biogeochem. Cy., 17(2), 1063, doi:10.1029/2002GB002004, 2003.

Mahowald, N. M., Engelstaedter, S., Luo, C., Sealy, A., Artaxo, P., Benitez-Nelson, C., Bonnet, S., Chen, Y., Chuang, P. Y., Cohen, D. D., Dulac, F., Herut, B., Johansen, A. M., Kubilay, N., Losno, R., Maenhaut, W., Paytan, A., Prospero, J. M., Shank, L. M., and Siefert, R. L.: Atmospheric Iron Deposition: Global Distribution, Variability, and Human Perturbations, Annual Review of Marine Science, 1, 245-278, doi:10.1146/annurev.marine.010908.163727, 2009.

Martin, J., Gordon, R., and Fitzwater, S.: Iron in Antarctic waters, Nature, 345, 156-158, 1990.

Martin, J. H.: Glacial-interglacial $\mathrm{CO}_{2}$ change: The iron hypothesis, Paleoceanography, 5, 1-13, 1990.

Mills, M., Ridame, C., Davey, M., La Roche, J., and Geider, R.: Iron and phosphorus co-limit nitrogen fixation in the eastern tropical North Atlantic, Nature, 429, 292-294, 2004.

Moffet, J.: Transformations among different forms of iron in the ocean, in: The Biogeochemistry of Iron in Seawater, edited by: Turner, D. and Hunter, K., SCOR/IUPAC Series, J. Wiley, 1-7, 2001.

Moore, J. K. and Braucher, O.: Sedimentary and mineral dust sources of dissolved iron to the world ocean, Biogeosciences, 5, 631-656, doi:10.5194/bg-5-631-2008, 2008.

Nyffeler, U., Li, Y.-H., and Santschi, P.: A kinetic approach to describe trace-element distribution between particles and solution in natural aquatic systems, Geochim. Cosmochim. Ac., 48, 1513-1522, 1984.

Onogi, K., Tsutsui, J., Koide, H., Sakamoto, M., Kobayashi, S., Hatshushika, H., Matshumoto, T., Yamazaki, N., Kamahort, H., Takahashi, K., Kadokura, S., Wada, K., Kato, K., Oyama, R., Ose, T., Mannoji, N., and Taira, R.: The JRA-25 Reanalysis, J. Meteorol. Soc. Jpn. Ser. II, 85, 369-432, 2007.

Parekh, P., Follows, M., and Boyle, E.: Modelling the global ocean iron cycle, Global Biogeochem. Cy., 18, GB1002, doi:10.1029/2003GB002061, 2004.

Pham, A. N., Rose, A. L., Feitz, A. J. and Waite, T. D.: Kinetics of $\mathrm{Fe}(\mathrm{III})$ precipitation in aqueous solutions at $\mathrm{pH}$ 6.0-9.5 and $25^{\circ} \mathrm{C}$, Geochim. Cosmochim. Ac., 70, 640-650, doi:10.1016/j.gca.2005.10.018, 2006.

Pulido-Villena, E., Rèrolle, V., and Guieu, C.: Transient fertilizing effect of dust in P-deficient LNLC surface ocean, Geophys. Res. Lett., 37, L01603, doi:10.1029/2009GL041415, 2010.

Reche, I., Ortega-Retuerta, E., Romera, O., Pulido-Villena, E., Morales-Baquero, R., and Casamayord, E.: Effect of Saharan dust inputs on bacterial activity and community composition in Mediterranean lakes and reservoirs, Limnol. Oceanogr., 54, 869879, 2009.

Ridame, C. and Guieu, C.: Saharan input of phosphate to the oligotrophic water of the open western Mediterranean Sea, Limnol. Oceanogr., 47, 856-869, 2002.

Rijkenberg, M., Powell, C., Dall'Osto, M., Nielsdottir, M., Patey, M., Hill, P., Baker, A., Jickells, T., Harrison, R., and Achterberg, E.: Changes in iron speciation following a Saharan dust event in the tropical North Atlantic Ocean, Mar. Chem., 110, 56-67, doi:10.1016/j.marchem.2008.02.006, 2008.

Rose, A. and Waite, T.: Predicting iron speciation in coastal waters from the kinetics of sunlight-mediated iron redox cycling, Aquat. Sci., 65, 375-383, 2003a.
Rose, A. and Waite, T.: Kinetics of hydrolysis and precipitation of ferric iron in seawater, Environ. Sci. Technol., 37, 3897-3903, 2003b.

Sarthou, G., Baker, A., Blain, S., Achterberg, E., Boye, M., Bowie, A., Croot, P., Laan, P., De Baar, H., Jickells, T., and Worsfold, P.: Atmospheric iron deposition and sea-surface dissolved iron concentrations in the eastern Atlantic Ocean, Deep-Sea Res. Pt. I, 50, 1339-1352, 2003.

Schartau, M. and Oschlies, A.: Simultaneous data-based optimization of a 1D-ecosystem model at three locations in the North Atlantic: Part I. Method and parameter estimates, J. Mar. Res., 61, 765-793, 2003a.

Schartau, M. and Oschlies, A.: Simultaneous data-based optimization of a 1D-ecosystem model at three locations in the North Atlantic: Part II. Standing stocks and nitrogen fluxes, J. Mar. Res., 61, 795-821, 2003b.

Sedwick, P. N., Church, T. M., Bowie, A. R., Marsay, C. M., Ussher, S. J., Achilles, K. M., Lethaby, P. J., Johnson, R. J., Sarin, M. M., and McGillicuddy, D. J.: Iron in the Sargasso Sea (Bermuda Atlantic Time-series Study region) during summer: Eolian imprint, spatiotemporal variability, and ecological implications, Global Biogeochem. Cy., 19, GB4006, doi:10.1029/2004GB002445, 2005.

Sohm, J. A. and Capone, D. G.: Phosphorus dynamics of the tropical and subtropical north Atlantic: Trichodesmium spp. versus bulk plankton, Mar. Ecol.-Prog. Ser., 317, 21-28, 2006.

Sunda, W. and Huntsman, S.: Iron uptake and growth limitation in oceanic and coastal phytoplankton, Mar. Chem., 50, 189-206, 1995.

Tagliabue, A., Bopp, L., Aumont, O., and Arrigo, K. R.: Influence of light and temperature on the marine iron cycle: From theoretical to global modeling, Global Biogeochem. Cy., 23, GB2017, doi:10.1029/2008GB003214, 2009.

Ternon, E., Guieu, C., Loÿe-Pilot, M.-D., Leblond, N., Bosc, E., Gasser, B., Miquel, J.-C., and Martín, J.: The impact of Saharan dust on the particulate export in the water column of the North Western Mediterranean Sea, Biogeosciences, 7, 809-826, doi:10.5194/bg-7-809-2010, 2010.

Thingstad, T., Li Zweifel, U., and Rassoulzadegan, F.: P limitation of heterotrophic bacteria and phytoplankton in the northwest Mediterranean, Limnol. Oceanogr., 43, 88-94, 1998.

Umlauf, L. and Burchard, H.: Second-order turbulence closure models for geophysical boundary layers. A review of recent work, Cont. Shelf Res., 25, 795-827, 2005.

Vink, S. and Measures, C.: The role of dust deposition in determining surface water distributions of $\mathrm{Al}$ and $\mathrm{Fe}$ in the South West Atlantic, Deep-Sea Res. Pt. II, 48, 2787-2809, 2001.

Wagener, T., Pulido-Villena, E., and Guieu, C.: Dust iron dissolution in seawater: Results from a one-year time-series in the Mediterranean Sea, Geophys. Res. Lett., 35, L16601, doi:10.1029/2008GL034581, 2008.

Wagener, T., Guieu, C., and Leblond, N.: Effects of dust deposition on iron cycle in the surface Mediterranean Sea: results from a mesocosm seeding experiment, Biogeosciences, 7, 3769-3781, doi:10.5194/bg-7-3769-2010, 2010.

Weber, L., Völker, C., Oschlies, A., and Burchard, H.: Iron profiles and speciation of the upper water column at the Bermuda Atlantic Time-series Study site: a model based sensitivity study, Biogeosciences, 4, 689-706, doi:10.5194/bg-4-689-2007, 2007. 
Wedepohl, K. H.: The composition of the continental crust, Geochim. Cosmochim. Ac., 59, 1217-1232, doi:10.1016/00167037(95)00038-2, 1995.

Wells, M. and Goldberg, E.: Colloid aggregation in seawater, Mar. Chem., 41, 353-358, 1993.

Wen, L.-S., Santschi, P., and Tang, D.: Interactions between radioactively labeled colloids and natural particles: Evidence for colloidal pumping, Geochim. Cosmochim. Ac., 61, 2867-2878, 1997.
Wu, J., Boyle, E., Sunda, W., and Wen, L.-S.: Soluble and colloidal iron in the oligotrophic North Atlantic and North Pacific, Science, 293, 847-849, 2001.

Ye, Y., Völker, C., and Wolf-Gladrow, D. A.: A model of Fe speciation and biogeochemistry at the Tropical Eastern North Atlantic Time-Series Observatory site, Biogeosciences, 6, 20412061, doi:10.5194/bg-6-2041-2009, 2009. 